\title{
Efektivitas Strategi Cyber Government Public Relations dalam Diseminasi Informasi Kesehatan sebagai Bentuk Komunikasi Krisis (Kasus: Informasi Kesehatan Covid-19 Masyarakat Kabupaten Bogor)
}

\author{
Effectiveness of Cyber Government Public Relations in Dissemination of Health \\ Information as a Form of Crisis Communication (Case: Covid-19 Health \\ Information Bogor Regency Community)
}

\author{
Fatima Alifha*), Dwi Retno Hapsari
}

${ }^{1}$ Departemen Sains Komunikasi dan Pengembangan Masyarakat, Fakulas Ekologi Manusia, IPB University, Dramaga, Kabupaten Bogor, 16680, Indonesia

${ }^{*}$ fatima_lifha@apps.ipb.ac.id

Diterima: 11-10-21 | Disetujui: 19-01-22 | Publikasi online: 20-01-22

\begin{abstract}
In March 2020, Indonesia was hit by the Covid-19 pandemic crisis, Including Bogor Region. Various efforts have been made by the government, one of them is the dissemination of health information by the Task Force for Handling Covid-19. Online dissemination is mainly done on the website, Instagram, Twitter, and Facebook. However, the number of Covid-19 transmissions and protocol violations is still increasing. Therefore, the purpose of this research is to see the effectiveness of the GPR cyber strategy of the Task Force for the Acceleration of Handling Covid-19 in the dissemination of health information as a form of crisis communication. The method used is an online survey research using a quantitative approach supported by qualitative data. Quantitative data was obtained using online questionnaires and qualitative data was conducted by in-depth interviews both online and face-to-face. Respondents were taken by voluntary sampling method. The result found a strong relationship between age and the level of website dissemination amongst other medias. Other elements of social structure only found a weak and insignificant relationship. The dissemination of information from website is related to the user assessment of it. Meanwhile, no relationship was found between attitudes and the level of disseminations of respondents in all medias.
\end{abstract}

Kata kunci: Cyber government public relations, Crisis communication, Health communication

\section{ABSTRAK}

Pada Maret 2020, Indonesia telah dilanda krisis pandemic Covid-19, termasuk Kabupaten Bogor. Berbagai upaya telah dilakukan pemerintah salah satunya dengan diseminasi informasi kesehatan oleh Gugus Tugas Percepatan Penanganan Covid-19 Kabupaten Bogor. Diseminasi secara online utamanya dilakukan pada website, Instagram, Twitter, dan Facebook. Namun, angka penularan Covid-19 dan pelanggaran protokol masih terus meningkat. Maka dari itu, tujuan dari penelitian ini adalah untuk melihat sejauh mana efektivitas strategi cyber GPR Gugus Tugas Percepatan Penanganan Covid-19 dalam diseminasi informasi kesehatan sebagai bentuk komunikasi krisis. Metode yang digunakan adalah metode penelitian survei online dengan menggunakan pendekatan kuantitatif yang didukung dengan data kualitatif. Data kuantitatif diperoleh dengan menggunakan kuesioner online dan data kualitatif dilakukan dengan wawancara mendalam baik secara online maupun tatap muka. Pengambilan responden dilakukan dengan voluntary sampling. Ditemukan hubungan yang cukup kuat antara usia dengan tingkat diseminasi website diantara media lainnya. Elemen struktur sosial lainnnya hanya ditemukan hubungan yang lemah dan tidak significant. Keterdedahan informasi dari media cyber website berhubungan dengan penilaian pengakses terhadap website tersebut. Sedangkan, tidak ditemukan hubungan antara sikap dengan tingkat keterdedahan responden pada seluruh media.

Kata kunci: Cyber government public relations, Komunikasi kesehatan, Komunikasi krisis 


\section{PENDAHULUAN}

Sebanyak 213 negara kini tengah dilanda pandemi Covid-19. Hingga 19 Agustus 2020, jumlah pasien Covid-19 di Indonesia telah mencapai 144.945 orang dan sebanyak 22.324 .108 orang di dunia (Worldometer.com 2020). Wilayah Jabodetabek menjadi kawasan berstatus red zone semenjak awal kemunculannya. Jakarta merupakan wilayah dengan kasus tertinggi. Kabupaten Bogor sebagai kawasan penyangga menjadi wilayah yang rawan tertular. Dilansir dari laman Covid-19.bogorkab.go.id, pada tanggal yang sama, terdapat 679 pasien terkonfirmasi positif di Kabupaten Bogor. Menurut Pasal 5 Undang-Undang Republik Indonesia Nomor 24 Tahun 2007 tentang Penanggulangan Bencana, yang pada intinya menyatakan pemerintah daerah bertanggung jawab dan berwenang atas penanggulangan bencana. Kriyantono (2018) dan Nova (2017) memaparkan strategi dan prinsip yang dapat digunakan oleh public relations (PR) dalam menghadapi krisis yakni: (1) membangun tim krisis dengan anggota lintas bidang selaras dengan pembagian kerja dari hasil perencanaan krisis agar lebih terkontrol dan terarah; (2) mengelola informasi secara cepat, tepat, jujur, sesuai fakta, diperbarui secara berkala, tetap menjaga reputasi instansinya, memperlihatkan rasa empati dan menggunakan sistem komunikasi satu pintu; serta (3) menggunakan beragam media secara bersamaan sehingga informasi dimungkinkan sampai ke penduduk dengan segmen yang berbeda-beda; dan (4) memelihara hubungan yang baik dengan publiknya.

Melihat kasus gempa bumi Lombok tahun 2018, Divisi Hubungan Masyarakat Kabupaten Lombok Utara membentuk tim krisis, pengelolaan informasi, penggunaan media dan menjalin hubungan dengan publik sebagai strategi komunikasi krisisnya. Tim krisis dikomandani oleh Kepala Badan Penanggulangan Bencana Daerah (BPBD) yang dijabat secara rangkap (ex-officio) oleh Sekretaris Daerah. Pos komando ini terdiri dari unit kerja berupa lima bidang dan enam seksi yang berasal dari Organisasi Perangkat Daerah/instansi/lembaga terkait sesuai dengan bidangnya masing-masing. Humas Pemerintah Daerah Kabupaten Lombok Utara sendiri berada pada Bidang Data dan Informasi. Peran dan tugasnya adalah melakukan peliputan dan publikasi terhadap kebijakan dan tahapan-tahapan yang telah dilakukan oleh pemerintah Lombok Utara dalam menangani krisis. Informasi yang diolah berupa: (1) informasi dasar yang terdiri dari perkembangan bencana, kebijakan pimpinan daerah serta perkembangan tahapan-tahapan yang sudah dilakukan terkait penanggulangan bencana; (2) informasi penanganan fisik (ajakan untuk kembali ke rumah dari lokasi pengungsian) dan psikis (membangkitkan semangat menggunakan tagline "Lombok Utara Bangkit, Lombok Utara Bangun Kembali"; (3) informasi himbauan untuk tetap tenang dan siaga; (4) informasi edukasi kebencanaan dengan membagikan video edukasi tsunami yang dibuat oleh Badan Meteorologi, Klimatologi, dan Geofisika (BMKG). Media-media yang digunakan beragam, baik media konvensional, media sosial, maupun special event. Kepala Bagian Humas Pemerintah Daerah Kabupaten Lombok Utara mengakui bahwa media sosial dapat dikatakan sebagai salah satu media paling efektif dalam proses penanggulangan bencana. Indikatornya adalah bahwa penyampaian informasi melalui media sosial tergolong efisien dan dapat dilakukan dengan cepat (Ulfa et al. 2018).

Sebagai upaya menghadapi Covid-19, Pemerintah Kabupaten Bogor menganggarkan dana sebesar Rp 384 miliar yang akan digunakan untuk menangani dampak kesehatan, ekonomi, serta jaring pengaman sosial (Khatimah 2020). Bupati Kabupaten Bogor mengeluarkan Surat Keputusan No 360/216/Kpts/PerUU/2020 tentang Pembentukan Gugus Tugas Percepatan Penanganan Covid-19 Kabupaten Bogor yang diketuai oleh Bupati Bogor. Gugus ini terdiri dari beberapa divisi, di antaranya "Divisi Pelayanan Informasi, Pusat Data dan TIK" dan "Divisi Komunikasi Publik" yang keduanya diorganisir oleh Dinas Komunikasi dan Informatika (DISKOMINFO) Kabupaten Bogor. Divisi Hubungan masyarakat (Humas) pada sektor pemerintahan, yang selanjutnya disebut Government Public Relations (GPR) berperan sebagai jembatan antara pemerintah dan masyarakat. Salah satu strategi public relations dalam publikasi informasi adalah dengan menggunakan media cyber. Government Public Relations (GPR) Pemerintah Kabupaten Bogor dalam peranya pada Gugus Tugas Percepatan Penanganan Covid-19 telah menerapkan strategu tersebut pada website https://Covid-19.bogorkab.go.id/, https://geoportal.bogorkab.go.id/covid19/ yang terhubung dengan media sosial Twitter (@bogorkab), Facebook (@bogorkab), dan Instagram (@kabupaten.bogor). Media ini aktif digunakan untuk komunikasi kesehatan Covid-19 sebagai bentuk penanganan krisis pandemi. 
Di era new media seperti sekarang ini, menggunakan internet sudah menjadi kebiasaan masyarakat. Sutrisno et al. (2019) membuktikan bahwa aktivitas mengakses media sosial sudah menjadi ritual. Seperti ritual pagi dimulai dengan menyeruput kopi panas bersamaan dengan membuka Facebook, saat dalam antrean mengakses Twitter, dan bahkan scrolling Instagram menjadi ritual sebelum tidur. Pulau Jawa merupakan pulau dengan pengguna internet tertinggi di Indonesia (95,3 juta jiwa) dengan Jawa Barat merupakan provinsi terkontributif terbesar (16,7\%). Lebih dari separuh penduduk Jawa Barat telah terpenetrasi internet $(58,3 \%)$ Penggunaan Internet di Indonesia juga tergolong tinggi baik di area rural maupun urban (APJI 2018). Ditambah dengan tuntutan untuk beraktivitas di rumah saja pada masa krisis pandemi Covid-19 membuat peningkatan penggunaan internet sebanyak 10\% (Kominfo 2020).

Penelitian yang dilakukan oleh Wahyudin dan Sugiana (2018) menemukan bahwa salah satu faktor penyebab terus bertambahnya korban kasus wabah difteri di tahun 2017 adalah kurangnya pengetahuan penduduk dan keyakinan penduduk terhadap pemerintah. Diseminasi informasi kesehatan yang dilakukan pemerintah berperan penting dalam mengubah sikap masyarakat. Mengingat maraknya penggunaan media cyber dan telah dilakukannya diseminasi informasi kesehatan Covid-19 secara online oleh Gugus tugas Percepatan Penanganan Covid-19 Kabupaten Bogor, masih terdapat penduduk yang tidak memedulikan anjuran pemerintah. Hal ini terlihat dari masih banyaknya kasus pelanggar Pembatasan Sosial Berskala Besar (PSBB) dan semakin meningkatnya kasus positif. Berbagai sanksi mulai diperketat seperti adanya denda Rp50.000,- bagi pelanggar penggunaan masker di tempat umum pada fase PSSB pra-adaptasi kebiasaan baru (Ayobogor 2020). Berdasarkan pemaparan tersebut, menarik bagi penulis untuk mengkaji lebih dalam mengenai sejauh mana efektivitas strategi $\boldsymbol{c y b e r}$ GPR Gugus Tugas Percepatan Penanganan Covid-19 dalam diseminasi informasi kesehatan sebagai bentuk komunikasi krisis?

\section{Tujuan Penelitian}

Berdasarkan pemaparan rumusan masalah di atas, tujuan penelitian ini adalah sebagai berikut: (1) Menganalisis hubungan antara karakteristik inndividu dengan tingkat diseminasi informasi kesehatan pada media cyber GPR Gugus Tugas Percepatan Penanganan Covid-19; (2) Menganalisis hubungan antara penilaian terhadap strategi cyber GPR dengan tingkat diseminasi informasi kesehatan Covid-19; (3) Mengana

\section{PENDEKATAN TEORITIS}

\section{Public relations}

Menurut Cutlip et al. (2006), PR merupakan suatu peran manajemen yang menciptakan serta menjaga hubungan yang baik dan bermanfaat antara organisasi dengan publik yang mempengaruhi kesuksesan atau kegagalan organisasi tersebut. Jefkins (1992) menyatakan bahwa PR adalah semua bentuk komunikasi yang terencana, baik itu ke dalam maupun ke luar, antara suatu organisasi dengan semua khalayaknya dalam rangka mencapai tujuan - tujuan spesifik yang berlandaskan pada saling pengertian berbagai pihak yang terlibat dalam proses produksi pesan-pesan komunikasi massa. Nova (2017) menyatakan PR bertugas untuk menumbuhkan dan mengembangkan hubungan baik antar lembaga (organisasi) dengan publiknya, internal maupun eksternal dalam rangka menanamkan pengertian, menumbuhkan motivasi dan partisipasi publik dalam upaya menciptakan iklim pendapat (opini publik) yang menguntungkan lembaga organisasi. Tujuan dari public relations adalah untuk membangun hubungan baik dengan publik melalui komunikasi dua arah yang simetris (Grunig dan Hunt 1984; Jo and Kim 2009). Berdasarkan uraian tersebut, public relations adalah sebuah fungsi manajemen terencana untuk membangun hubungan baik, internal maupun eksternal, demi mencapai tujuan spesifik yang mampu memberikan manfaat kepada kedua belah pihak baik dalam bentuk kerja sama, peningkatan produktivitas serta efisiensi perusahaan.

\section{Strategi public relations}

Strategi dalam dunia PR diartikan sebagai konsep, pendekatan, atau rencana umum untuk program yang didesain guna mencapai tujuan. Strategi komunikasi PR dimaknai sebagai isi pesan apa yang harus disampaikan untuk mencapai hasil seperti dinyatakan dalam sasaran program (Cutlip et al. 2006). Artis 
(2011) dalam penelitiannya yang berjudul "Strategi Komunikasi Public Relations" menyimpulkan bahwa strategi PR dalam usaha menjalin berbagai hubungan positif dengan publik internal dan eksternal merupakan peranan PR dalam ragam aktivitas seperti menginformasikan, menerangkan, menyarankan, membujuk, mengundang, dan meyakinkan. Komunikasi berguna untuk menafsirkan dan mendukung strategi aksi yang dilakukan organisasi dalam menanggapi suatu problem. Strategi komunikasi PR akan mendukung program aksi dengan cara memberi informasi pada publik, membujuk publik untuk mendukung dan menerima tindakan tersebut, serta memberi petunjuk kepada publik mengenai cara menerjemahkan niat ke dalam aksi. Mengetahui publik sasaran ini akan berguna untuk menyusun strategi komunikasi yang tepat sasaran dalam penelitian ini adalah penduduk Kabupaten Bogor yang ter diseminasi informasi kesehatan Covid-19 melalui media cyber yang digunakan oleh Gugus Tugas Percepatan Penanganan Covid-19 Kabupaten Bogor.

\section{Strategi cyber PR}

Menurut Onggo (2004), Cyber PR merupakan Inisiatif PR yang menggunakan media internet sebagai sarana publisitasnya. PR dapat memanfaatkan potensi-potensi besar seperti: (1) komunikasi konstan, (2) respons yang cepat, (3) pasar global, (4) interaktif, (5) komunikasi dua arah, (6) hemat. Hidayat (2013) menyatakan bahwa Cyber PR adalah inisiatif sebagai cara atau strategi kerja akademisi dan praktisi public relations dengan menggunakan media internet sebagai sarana publisitasnya. Sari (2009) menyebutkan bahwa Cyber PR mampu membentuk hubungan one-to-one (paling efektif pada media sosial), komunikasi massa, serta pemasaran. Cyber PR dapat menyampaikan informasi tentang kebijakan publik, mensosialisasikan kebijakan pemerintahan, serta menjaga hubungan baik dengan para stakeholders sehingga hal tersebut menciptakan positif image dan opini publik yang baik. Berdasarkan paparan tersebut, yang dimaksud dengan Cyber PR adalah inisiatif PR dengan menggunakan internet sebagai media publisitas. Potensi berkomunikasi yang dapat dilakukan lebih luas seperti membentuk hubungan one-to-one, komunikasi massa, pemasaran yang dapat dilakukan secara konstan, respons cepat, menjangkau pasar global, interaktif, dua arah, serta hemat.

\section{Penilaian media cyber PR}

Penelitian yang dilakukan Barnes dan Vidgen (2003) menggunakan metode WebQual untuk menilai kualitas dari website Forum on Strategic Management Knowledge Exchange (FSMKE). Situs ini merupakan cross-national e-government organization mengenai kebijakan dan administrasi pajak internasional. WebQual pertama kali dibentuk sebagai instrumen untuk menilai persepsi pengguna terhadap kualitas website e-commerce. Instrumen-instrumen yang terkandung di dalamnya telah dikembangkan sejak 1998 dan terus berkembang melalui proses penyempurnaan berulang di berbagai domain e-commerce dan e-government. Metode ini mengubah pengukuran kualitatif pengguna menjadi pengukuran kuantitatif yang sangat berguna untuk manajemen pembuatan keputusan (Barnes dan Vidgen 2003). Lebih lanjut, Barnes dan Vidgen 2003 menyatakan bahwa WebQual 4.0, mengacu pada penelitian dari tiga area inti, yakni:

1. Kualitas informasi, berdasarkan kajian sistem informasi secara umum.

2. Kualitas pelayanan dan interaksi, berdasarkan kajian dari marketing, e-commerce, dan penelitian mengenai kualitas sistem; dan

3. Kegunaan, berdasarkan kajian dari interaksi antara manusia dengan komputer.

Barnes dan Vidgen (2003) juga kerap memperbaharui instrumen ini dengan menggunakan lokakarya berkualitas di setiap tahap pengembangan WebQual. Ini dilakukan demi memastikan kualitas relevansinya. Terutama jika terkait dengan literatur pra-Internet dan pengaturan organisasi atau industri baru. Berikut standar pertanyaan instrumen WebQual 4.0 yang terdiri dari 23 pertanyaan yang dapat dilihat pada Tabel 1. Website yang diteliti oleh Barnes dan Vidgen (2003) berkarakter informationintensive. Maka dari itu, pertanyaan nomor 17, 18 serta 22 dihapuskan. 


\begin{tabular}{ll}
\hline Kegunaan & 1. Saya menemukan situs ini mudah untuk dipelajari \\
2. Inn dioperasikan \\
2. Interaksi saya dengan situs ini jelas dan dapat \\
3. Samengerti \\
4. Menurut saya situs ini mudah digunakan \\
5. Situs memiliki tampilan yang menarik \\
6. Desain sesuai dengan jenis situs \\
7. Situs ini mengambarkan rasa kompetensi \\
8. Situs ini memberikan pengalaman positif bagi saya \\
9. Memberikan informasi yang akurat \\
10. Memberikan informasi yang dapat dipercaya \\
11. Memberikan informasi sesuai waktunya \\
12. Memberikan informasi yang relevan \\
13. Memberikan informasi yang mudah dipahami \\
14. Memberikan informasi pada tingkat detail yang tepat \\
15. Menyajikan informasi dalam format yang sesuai \\
Kualitas pelayanan
\end{tabular}

Sumber: Barnes dan Vidgen (2003)

Mulya (2020) dalam meneliti efektivitas Facebook desa sebagai media penyebaran informasi pembangunan desa juga menggunakan instrumen WebQual 4.0 tersebut yang diadaptasi (dapat dilihat pada Tabel 3). Instrumen ini dipaparkan pada Tabel 2. Penelitian Mulya (2020) dan penelitian Mulyawaty (2016) dalam meneliti efektivitas media cyber 1 dalam penyebaran informasi di desa menggunakan instrumen WebQual tersebut untuk menganalisis persepsi pengaksesnya. Persepsi tersebut diukur menggunakan skala likert 1-4 (sangat tidak setuju-sangat setuju).

1 Facebook Desa Curug Kabupaten Bogor (Mulya 2020) dan Website Desa Malasari, Kabupaten Bogor (Mulyawaty 2016) 


\begin{tabular}{ll}
\hline \multicolumn{1}{c}{ Dimensi website } & \multicolumn{1}{c}{ Deskripsi Indikator } \\
\hline \multirow{2}{*}{ Usability (Kegunaan) } & Kemudahan untuk dioperasikan. \\
& Interaksi dengan Facebook desa mudah dimengerti \\
& Tampilan yang atraktif. \\
& Menyediakan informasi yang akurat \\
Kualitas Informasi & Menyediakan informasi yang dapat dipercaya. \\
& Menyediakan informasi yang up to date. \\
& Menyediakan informasi yang relevan. \\
& Menyediakan informasi yang cukup detail. \\
Kualitas interaksi pelayanan & Mempunyai reputasi yang baik. \\
& Rasa aman dalam berinteraksi \\
& Kemudahan untuk menarik minat dan perhatian. \\
\hline Sdanya suasana komunitas.
\end{tabular}

Sumber: Mulya (2020)

Hasil penelitian Mulya (2020) membuktikan bahwa tingkat kualitas interaktif berkaitan dengan ketertarikan dan rasa aman dalam berinteraksi dalam Facebook desa serta reputasinya di kalangan responden. Semakin tingkat kualitas interaktif dinilai tinggi oleh responden, maka semakin tinggi pula tingkat keterdedahan terhadap Facebook. DeLone dan McLean (2003) dalam penelitiannya mengenai manajemen sistem informasi membuktikan bahwa kualitas informasi dan kualitas pelayanan berpengaruh positif terhadap tingkat kepuasan pengguna dan intensitas penggunaan layanan suatu sistem informasi.

Robbins dan Judge (2012) menyatakan bahwa persepsi adalah proses pengorganisasian dan penerjemahan kesan indrawi yang dilakukan oleh individu untuk memberi makna terhadap lingkungan mereka. Pemahaman yang salah terhadap pola pikir publik hanya akan menyebabkan informasi yang disalurkan tidak bisa bertahan lama (Wasesa 2006). Cutlip et al. (2006) juga menyatakan bahwa dalam mengurangi diskrepansi antara posisi komunikator dengan sikap audiens dalam konteks PR, diperlukan penggunaan media yang paling dekat pandangannya dengan pandangan audiens. Mendengar sistematis pandangan publik merupakan bentuk feedback yang penting bagi organisasi. Schramm (1973) menyatakan bahwa feedback akan memberitahu kepada komunikator tentang bagaimana pesanya diterima oleh pihak lain.

\section{Government Public Relations (GPR)}

Berdasarkan Peraturan Menteri Dalam Negeri Nomor 13 Tahun 2011 tentang Pedoman Pelaksanaan Tugas Kehumasan di Lingkungan Kementerian Dalam Negeri dan Pemerintah Daerah, pada intinya menyatakan bahwa humas pemerintah merupakan "aktivitas lembaga dan atau individu penyelenggara pemerintahan, yang melakukan fungsi manajemen dalam bidang komunikasi dan informasi kepada publik pemangku kepentingan dan sebaliknya". Hubungan masyarakat (humas) yang terdapat di instansi pemerintah dengan non pemerintah (lembaga komersial) adalah tidak adanya unsur komersial walaupun humas pemerintah juga melakukan hal yang sama dalam kegiatan publikasi, promosi dan periklanan. Menurut Ruslan (2012) GPR lebih menekankan pada public service demi meningkatkan pelayanan umum. Menurut Cutlip et al. (2006), tujuan public affairs dalam pemerintahan yang selanjutnya disebut hubungan penduduk adalah menggunakan informasi yang melimpah dan akurat oleh pemerintah yang demokratis untuk menjaga hubungan yang responsif dengan konstituen, berdasarkan pada pemahaman bersama dan komunikasi dua arah yang terus menerus. Salah satu tujuan humas pemerintahan yakni membangun komunitas bangsa dengan menggunakan kampanye kesehatan publik serta mempromosikan program sosial dan pembangunan. Berdasarkan uraian tersebut, dapat disimpulkan bahwa humas pemerintah, yang selanjutnya disebut dengan Government Public Relations (GPR) adalah bentuk public relations non komersial yang dijalankan oleh lembaga pemerintahan yang menekankan pada pelayanan penduduk dalam bidang komunikasi yang bersifat responsif serta publisitas utamanya merupakan informasi-informasi publik. 


\section{Strategi cyber GPR}

Strategi cyber PR telah diterapkan oleh GPR. Keunggulan yang diberikan dalam penggunaan media baru berbasis internet tanpa batas waktu dan tempat ini mampu mendukung tujuan GPR untuk membangun masyarakat. Seperti dalam penelitian yang dilakukan oleh Wardah (2017), dengan hadirnya program pengaduan penduduk berbasis teknologi internet, penduduk menjadi lebih mudah mengakses informasi publik melalui website dengan menggunakan gawai. Penelitian yang dilaksanakan oleh Susilowati dan Paryanta (2015) juga membuktikan bahwa penataan informasi yang dilakukan secara teratur, jelas, tepat dan cepat serta dapat disajikan dalam aplikasi dan laporan tentunya sangat mendukung kelancaran kegiatan operasional pemerintah desa. Kinerja pemerintah desa akan menjadi lebih baik, lebih efisien dan lebih mudah terutama dalam sistem informasi. Kemudahan ini akan menguntungkan dalam pemberian pelayan dan penyebaran informasi kepada masyarakat. Informasi penting untuk membuat keputusan strategis. Kemudahan pengaksesan pelayanan membuat pemerintah menjadi lebih cepat mengetahui apa yang sesungguhnya terjadi dan dialami oleh masyarakat. Hal ini menjadi modal awal bagi pemerintah dalam merencanakan dan melaksanakan programnya sehingga dapat didukung secara positif pula oleh penduduk (Wardah 2017; Susilowati dan Paryanta 2015).

Penerapan strategi cyber PR oleh GPR bertujuan untuk mengaplikasikan keterbukaan informasi publik sesuai dengan Undang-Undang No. 14 tahun 2008 tentang Keterbukaan Informasi Publik, yang diperkuat dengan Peraturan Pemerintah No. 61 tahun 2010 tentang Pelaksanaan Undang-Undang No. 14 Tahun 2008 tentang Keterbukaan Informasi Publik, dan Peraturan Presiden No. 81 Tahun 2010 (Wardah 2017). Penduduk membutuhkan media yang cepat dan mudah untuk menyampaikan aspirasi dan pengaduan. Mereka juga memiliki hak yang sama untuk mendapatkan informasi seperti: pemberitaan, informasi pekerjaan, pelayanan, pembangunan infrastruktur, pendidikan serta persoalan lingkungan. Pemerintah berperan untuk menyediakan media komunikasi yang cepat seperti website yang memungkinkan pemerintah mampu menanggapi masukan, kritik yang membangun, sebagai media informasi publik, sarana komunikasi dan informasi yang transparan kepada masyarakat.

\section{Strategi cyber GPR Gugus Tugas Percepatan Penanganan Covid-19 Kabupaten Bogor}

Peran GPR pemerintahan Kabupaten Bogor dilaksanakan oleh Dinas Komunikasi dan Informatika (Diskominfo). Diskominfo Kabupaten Bogor memiliki tugas utama membantu bupati dalam melaksanakan urusan pemerintahan pada Bidang Komunikasi dan Informatika, Bidang Persandian, serta tugas pembantuan. Diskominfo terdiri dari divisi Sekretariat, Bidang Pengelolaan Informasi dan Komunikasi Publik, Bidang Penyelenggaraan E-Government, UPT Radio dan Televisi Siaran Pemerintah Daerah, serta Bidang Layanan Komunikasi Dan Informatika. Tujuan dari lembaga ini adalah tata kelola komunikasi dan informatika yang efektif dengan sasaran komunikasi dan informatika yang cepat dan terpercaya. Indikator kinerja utamanya menggunakan Indeks Sistem Pemerintahan Berbasis Elektronik serta diseminasi informasi melalui media. (Diskominfo Kabupaten Bogor 2020).

Bupati Kabupaten Bogor mengeluarkan Surat Keputusan No. 360/216/Kpts/Per-UU/2020 tentang Pembentukan Gugus Tugas Percepatan Penanganan Covid-19 Kabupaten Bogor yang diketuai oleh Bupati Bogor. Gugus ini terdiri dari beberapa divisi, di antaranya "Divisi Pelayanan Informasi, Pusat Data dan TIK" dan "Divisi Komunikasi Publik" yang keduanya diorganisir oleh Dinas Komunikasi dan Informatika (DISKOMINFO) Kabupaten Bogor.

Website Covid-19.bogorkab.go.id memiliki fitur home, info grafis, PSBB (berisikan tentang informasi serta laporan mengenai PSBB), nomor telepon darurat Covid-19, hyperlink website https://geoportal.bogorkab.go.id/covid19, hyperlink dengan website perkembangan Covid-19 di Jawa Barat (https://pikobar.jabarprov.go.id/), Indonesia (https://www.covid19.go.id/), dan dunia (https://gisanddata.maps.arcgis.com) serta dihubungkan pula dengan laman media sosial yakni Twitter, Facebook (keduanya memiliki nama akun @bogorkab), dan Instagram (@kabupaten.bogor). Media ini tertera pada bagian bawah laman web Covid-19.bogorkab.go.id. Informasi Covid-19 yang diperbaharui pada website akan didiseminasikan pula pada media sosial tersebut tepatnya setiap pukul 7 malam. 
Analisis strategi cyber GPR Kabupaten Bogor pada Gugus Tugas Percepatan Penanganan Covid-19 dilakukan menggunakan adaptasi WebQual 4.0. Adaptasi ini mempertimbangkan hal-hal sebagai berikut:

1. Dimensi efektivitas Facebook desa yang digunakan dalam penelitian Mulya (2020);

2. Syarat penyebaran informasi yang efektif (Sastropoetro 1990);

3. Karakteristik konten yang sangat berpengaruh adalah tingkat kelengkapan dan kejelasan informasi, desain visual, dan tipografi (Adhanisa dan Fatchiya 2017);

4. Website berfungsi sebagai media yang menyediakan informasi mendetail. media sosial seperti Instagram harus memperhatikan penggunaan tata bahasa. Website dianggap sebagai media untuk informasi sedangkan media sosial sebagai media untuk berinteraksi. (Sutrisno et al. 2019; Adhanisa dan Fatchiya 2017).

Maka, terbentuklah instrumen tingkat penilaian terhadap strategi cyber GPR Gugus Tugas Percepatan Penanganan Covid-19 Kabupaten Bogor pada Tabel 6. Persepsi responden akan dianalisis dengan penilaian mereka menggunakan skala likert 1-4 (sangat tidak setuju-sangat setuju) yang selanjutnya akan dianalisis keterhubungannya dengan variabel diseminasi informasi kesehatan Covid-19. Skala likert digunakan untuk mengukur komponen sikap pada variabel Y. Skala likert yang digolongkan ke dalam skala ordinal, mempunyai empat atau lebih butir-butir pertanyaan yang dikombinasikan sehingga membentuk sebuah skor/nilai yang merepresentasikan sifat individu, misalkan pengetahuan, sikap, dan perilaku (Budiaji 2013). Penelitian yang dilakukan oleh Setyaningrum (2016) dan Mulya (2020) juga mengukur penilaian ini dengan menggunakan skala likert.

Tabel 3 Dimensi penilaian strategi cyber GPR pada website

\section{Dimensi penilaian strategi cyber GPR \\ Deskripsi Indikator}

\begin{tabular}{ll}
\hline & 1) Saya merasa bahwa situs ini mudah untuk \\
digunakan \\
2) Kemudahan menemukan alamat website \\
2) Sility (Kegunaan) & 3) Situs ini memiliki tampilan yang atraktif. \\
4) Adanya penambahan pengetahuan dari informasi \\
pada website \\
1) Menyediakan informasi yang akurat \\
2) Menyediakan informasi yang dapat dipercaya. \\
Kualitas Informasi & 3) Menyediakan informasi terbaru \\
& 4) Menyediakan informasi yang mudah dibaca dan \\
dipahami \\
5ualitas interaksi pelayanan & 5) Menyediakan informasi yang mendetail \\
& 2) Kemudahan untuk menarik minat dan perhatian \\
3) Adanya suasana komunitas \\
4) Kepercayaan tinggi atas informasi yang \\
disampaikan
\end{tabular}

Media sosial memiliki fitur dan fungsi yang berbeda dengan website. Maka dari itu, dimensi penilaian strategi cyber GPR pada media sosial akan dianalisis dengan indikator sebagai berikut. 
Tabel 4 Dimensi penilaian strategi cyber GPR pada media sosial Instagram, Twitter dan Facebook

Dimensi penilaian

strategi cyber GPR

Deskripsi Indikator

\begin{tabular}{lll}
\hline & 1) & Kemudahan menemukan alamat akun media cyber \\
Usability (Kegunaan) & 2) & Tampilan yang atraktif. \\
& 3) & Adanya penambahan pengetahuan dari informasi dari media \\
& 1) & Mesial \\
Kualitas Informasi & 2) & Menyediakan informasi yang akurat \\
& 3) & Menyediakan informasi yang dapat dipercaya. \\
& 4) & Menyediakan informasi yang mudah dibaca dan dipahami \\
& 1) & Mempunyai reputasi yang baik \\
Kualitas interaksi & 2) & Rasa aman dalam bertransaksi. \\
pelayanan & 3) & Kemudahan untuk menarik minat dan perhatian \\
& 4) & Kemudahan untuk memberi masukan (feedback) \\
& 5) & Adanya suasana komunitas \\
& 6) & Kepercayaan tinggi atas informasi yang disampaikan \\
\hline
\end{tabular}

Responden hanya akan menilai dimensi-dimensi media cyber utama yang digunakannya untuk mencari informasi seputar Covid-19. Hal ini dimaksudkan untuk meminimalisir bias analisis pada efek yang ditimbulkan. Penelitian terhadap media cyber spesifik pemerintah daerah ini dianggap tepat dikarenakan media ini menyediakan informasi spesifik mengenai situasi dan kondisi daerah tempat tinggalnya. Berbeda dengan informasi yang didiseminasikan pada media nasional seperti press release Gugus Tugas Covid-19 Nasional yang memberikan informasi secara general.

\section{Diseminasi informasi kesehatan}

Menurut Rusdiana (2014), diseminasi merupakan penyebaran inovasi yang direncanakan, diarahkan, dan dikelola. Dibandingkan dengan difusi yang bersifat spontan, diseminasi bersifat terencana. Hal ini selaras dengan apa yang dikatakan (Wijaya et al. 1922) bahwa diseminasi mengarah pada suatu pola difusi yang terencana, yang di dalamnya beberapa biro (agency) mengambil langkah-langkah khusus untuk menjamin agar suatu pembaharuan akan mencapai jumlah pengadopsi (penyerapan pembaharuan) paling banyak. Menurut McQuails (2010), esensi dari informasi adalah pengurangan ketidakpastian. Sastropoetro (1990) menyatakan bahwa penyebaran informasi merupakan diseminasi pesan yang mengandung fakta sehingga mampu menghasilkan penjelasan yang benar dan jelas, serta bermakna sama. Hasil riset Kusumajanti et al. (2018) pada Humas Kementerian Kelautan dalam meningkatkan public awareness, diseminasi informasi yang terjadi berupa suatu kegiatan yang ditujukan kepada kelompok atau individu agar mereka memperoleh informasi, timbul kesadaran, menerima, dan akhirnya memanfaatkan informasi tersebut. Ketika menyebarkan suatu informasi, komunikan harus memperhatikan prinsip pengelolaan dan desain unsur-unsur komunikasi dengan baik sehingga penyampaian pesan dapat dilakukan secara efektif. Tujuan komunikasi tersebut salah satunya untuk penyebarluasan suatu kebijakan serta mendapatkan pemahaman dari masyarakat. Berdasarkan uraian tersebut, yang dimaksud diseminasi informasi adalah proses penyebaran informasi yang direncanakan yang bertujuan untuk mencapai kesamaan makna serta mengurangi ketidakpastian. Syarat penyebaran informasi yang efektif menurut Sastropoetro (1990) yaitu:

" (1) pesan yang disebarkan haruslah disusun secara jelas, mantap, dan singkat agar mudah ditangkap. Perlu dipahami bahwa tiap orang mempunyai daya tangkap yang berbeda. Dengan demikian penyebaran pesan haruslah menyusun pesan menurut perhitungan yang dapat ditangkap oleh orang lain atau sebagian besar orang yang berkepentingan; (2). lambanglambang yang digunakan haruslah dapat dipahami, dimengerti oleh mereka yang menjadi sasaran, artinya jikalau menggunakan bahasa, pergunakanlah bahasa yang dapat dimengerti; (3) pesan yang disampaikan atau disebarkan hendaknya dapat menimbulkan minat; (4) perhatian, dan keinginan pada si penerima pesan untuk melakukan sesuatu; (5) pesan-pesan yang disampaikan atau disebarkan hendaknya menimbulkan keinginan untuk memecahkan masalah, sekiranya ada masalah" 
Selain hal tersebut, keberhasilan penyebaran informasi juga ditentukan oleh media yang digunakan sebagai salurannya, baik yang sifatnya langsung seperti komunikasi tatap muka atau komunikasi yang termediasi teknologi.

\section{Komunikasi Kesehatan}

Menurut Budi (2010), komunikasi merupakan cara penyajian pesan antar manusia. Maka dari itu, ilmu komunikasi adalah ilmu yang meneliti usaha penyampaian pesan antar manusia sedangkan menurut Griffin (2012), komunikasi adalah proses relasional dalam menciptakan dan menginterpretasikan pesan yang mendapat respons. Komunikasi memusatkan bidang kajiannya pada bagaimana tingkah laku manusia dalam menciptakan, mempertukarkan, serta menginterpretasi pesan yang memiliki tujuan tertentu (Daryanto 2014). Dari uraian tersebut, dapat diketahui bahwa komunikasi merupakan proses transfer informasi, pemaknaan, serta interpretasi pesan antar orang yang memiliki tujuan tertentu.

Menurut World Health Organization (WHO) yang dimaksud sehat adalah keadaan fisik, sosial, dan mental yang lengkap. Bukan sekadar ketiadaan penyakit. Dinas Kesehatan Kabupaten Bogor (2017) juga menyatakan bahwa kesehatan merupakan kondisi sejahtera dari badan, jiwa, serta sosial yang memungkinkan setiap orang hidup produktif secara sosial dan ekonomis. Berdasarkan definisi tersebut, dapat dipahami bahwa kondisi sehat bukan hanya dilihat secara fisik saja, namun juga mempertimbangkan faktor-faktor sosial lainnya.

Komunikasi kesehatan merupakan studi yang mempelajari bagaimana cara menggunakan strategi komunikasi untuk menyebarluaskan informasi kesehatan yang dapat mempengaruhi individu dan komunitas sehingga mampu membuat keputusan yang tepat terkait dengan pengelolaan kesehatan (Liliweri 2008). Menurut Notoatmodjo (2007), komunikasi kesehatan adalah upaya terpadu untuk mempengaruhi secara positif perilaku kesehatan masyarakat, dengan menggunakan berbagai prinsip dan metode komunikasi, baik secara komunikasi interpersonal, maupun komunikasi massa. Tujuan utama komunikasi kesehatan adalah perubahan perilaku kesehatan masyarakat yang selanjutnya perilaku penduduk yang sehat tersebut akan berpengaruh kepada meningkatnya derajat kesehatan penduduk (Yusriani dan Alwi 2018). Komunikasi kesehatan merupakan strategi komunikasi untuk diseminasi informasi kesehatan agar penduduk termotivasi untuk berperilaku positif terhadap kesehatannya.

Tingkat diseminasi informasi dapat dilihat melalui keterdedahan penduduk akan informasi tersebut yang disebarkan melalui media cyber GPR. Menurut Rodman (2006), yang dimaksud dengan keterdedahan adalah proses pencarian pesan oleh individu untuk mencari pesan yang dapat membantunya dalam menentukan sikap. De Fleur (1989) menyatakan bahwa keterdedahan pada media dapat dilihat dari total waktu rata-rata yang digunakan dalam sehari, frekuensi, dan pilihan acara. Penelitian yang dilakukan Mulya (2020), Tede (2012), dan Dewi (2011) melihat keterdedahan dari indikator frekuensi dan lama khalayak memanfaatkan media massa (intensitas) pencarian informasi pada suatu media. Setyaningrum (2017) dalam analisisnya terhadap keterdedahan internet masyarakat Desa Campurejo melihat pilihan acara dengan menambahkan jenis layanan internet yang diakses. Jenis layanan ini menjadi salah satu indikator dalam pengukuran keterdedahan karena dapat menganalisis kemampuan responden dalam memanfaatkan berbagai layanan internet yang memiliki perbedaan cara akses serta penggunaan dalam pengoperasian layanan tersebut.

Diseminasi informasi kesehatan pada kasus ini akan dianalisis dari frekuensi, intensitas, serta jenis media cyber yang diakses oleh penduduk Kabupaten Bogor dalam mencari informasi Covid-19, khususnya informasi Covid-19 yang terjadi di Kabupaten Bogor. Penyabar luasan informasi dianggap berhasil jika adanya perubahan sikap sebagai efek dari penerima informasi. Menurut Hartono (2016), sikap adalah reaksi tertutup seseorang akan rangsangan atau obyek, baik yang bersifat internal maupun eksternal, yang sudah melibatkan faktor pendapat dan emosi yang bersangkutan (senang - tidak senang, setuju - tidak setuju, baik- tidak baik) sehingga penampakannya tidak terlihat secara langsung. Sikap merupakan organisasi pendapat, keyakinan seseorang akan objek atau situasi nyata, dengan adanya perasaan tertentu yang menjadi dasar untuk merespons atau berperilaku dengan cara tertentu yang dipilihnya. Sikap adalah predisposisi atau preferensi lintas-situasional berkenaan dengan sebuah objek. Sikap mengarahkan individu untuk merespons objek dengan cara tertentu dari satu situasi ke situasi lainnya, berdasarkan pengumpulan dan penilaian informasi dan pengalaman hidup (Cutlip et al. 
2006). Menurut Azwar (2011), sikap merupakan hasil persepsi dari pengetahuan yang diterima sebagai sesuatu yang positif atau negatif yang akan mempengaruhi perilaku individu. Sikap dipengaruhi oleh faktor pengalaman pribadi, pengaruh orang lain yang dianggap penting, kebudayaan, media massa, lembaga pendidikan, dan emosional. Sikap terdiri dari sistem yang terintegrasi dalam mode respons individu secara kognitif (pengetahuan dan kepercayaan), afektif (perasaan), dan konatif (kecenderungan berperilaku (Crespi 1997; Hartono 2016). Komponen-komponen tersebut dijelaskan lebih lanjut sebagai oleh Hartono (2016) sebagai berikut:

1 Komponen kognitif, berisi kepercayaan seseorang mengenai apa yang berlaku atau apa yang benar bagi objek sikap. Kepercayaan tersebut berdasarkan apa yang dilihat dan diketahui (pengetahuan), keyakinan, pikiran, pengalaman pribadi, dan informasi dari orang lain.

2 Komponen afektif menyangkut masalah emosional subyektif seseorang terhadap suatu objek sikap, baik yang positif (rasa senang) maupun yang negatif (rasa tidak senang). Reaksi emosional yang dipengaruhi oleh apa yang kita percayai benar terhadap objek sikap tersebut.

3 Komponen konatif menunjukkan bagaimana kecenderungan berperilaku yang ada dalam diri seseorang yang berkaitan dengan objek sikap yang dihadapinya. Perilaku seseorang ditentukan oleh kepercayaan dan perasaannya terhadap objek tersebut.

Penelitian ini akan berfokus dengan pengaruh media massa, yakni media cyber yang digunakan GPR Kabupaten Bogor pada Gugus Tugas Penanganan Percepatan Covid-19 dalam diseminasi informasi Covid-19. Tede (2012) dan Andika (2008) membuktikan bahwa semakin tinggi frekuensi dan intensitas penggunaan media, semakin besar kemungkinan khalayak untuk mendapatkan berbagai informasi

\section{Krisis}

Menurut Sellnow dan Seeger (2013), krisis adalah kondisi dimana kekuatan sosial, politik, ekonomi dan lingkungan yang menjadi semakin penting sehingga menciptakan lebih banyak perubahan secara lebih cepat dibandingkan fenomena tunggal lainnya. Krisis berpotensi menimbulkan kerugian yang besar, menimbulkan gangguan yang meluas secara sistematis. Namun, krisis juga dapat menjadi kekuatan untuk perubahan, pertumbuhan, dan pembaruan yang konstruktif. Krisis dapat dengan cepat membentuk kembali institusi, membuat perubahan dalam demografi dan populasi, mengubah ekosistem, merusak stabilitas ekonomi dan mengubah kepercayaan yang dianut secara luas. Kriyantono (2018) menyatakan bahwa krisis biasanya bersifat spesifik, tidak diharapkan, dapat terjadi setiap saat dan merupakan rangkaian beberapa kejadian, menimbulkan ketidakpastian informasi, dapat mengancam tujuan-tujuan organisasi, peristiwa yang memungkinkan memiliki pengaruh negatif terhadap organisasi. Combs (2012) menyatakan bahwa krisis adalah persepsi dari keadaan yang tidak dapat diprediksi yang mengancam harapan penting pemangku kepentingan dan dapat berdampak serius pada kinerja organisasi dan menghasilkan hasil negatif. Menurut Argenti (2009), terdapat tiga kondisi umum yang terjadi dalam krisis yakni: (1) elemen-elemen yang sifatnya tidak terduga; (2) informasi yang tidak mencukupi; dan (3) begitu cepatnya dinamika yang terjadi. Krisis merupakan peristiwa tak terduga yang berdampak pada perubahan yang sangat cepat sehingga menghasilkan kerancuan informasi.

\section{Krisis Covid-19 Indonesia}

Dilansir pada laman halodoc.com, virus ini pertama kali masuk pada tanggal 14 Februari 2020 dengan penularan pada acara pesta dansa yang dihadiri oleh peserta multinasional. Pada tanggal 2 Maret 2020, Presiden Joko Widodo secara resmi mengumumkan dua warga negara Indonesia positif terinfeksi Covid-19. Pasien pertama yang terkonfirmasi positif di Kabupaten Bogor juga merupakan salah satu peserta dari pesta dansa tersebut. Dilansir pada kompas.com, beliau mulai diperiksa darah dan rontgen di Rumah Sakit Persahabatan pada tanggal 12 Maret 2020. Lalu, pada tanggal 13 Maret 2020, pemerintah secara resmi membentuk Gugus Tugas Percepatan Penanganan Covid-19 dengan mengeluarkan Keputusan Presiden RI No. 7 Tahun 2020 tentang Gugus Tugas Percepatan Penanganan Corona Virus Disease 2019 (Covid-19) yang telah diubah terakhir kali dengan Keputusan Presiden RI No.9 Tahun 2020 tentang Perubahan Atas Keputusan Presiden Nomor 7 Tahun 2020 tentang Gugus Tugas Percepatan Penanganan Corona Virus Disease 2019 (Covid-19). Pembentukan gugus ini ditujukan untuk meningkatkan ketahanan nasional dibidang kesehatan, meningkatkan sinergi antar kementerian/lembaga dan pemerintah daerah, antisipasi eskalasi penyebaran dan meningkatkan 
kesiapan, kemampuan dalam mencegah, mendeteksi dan merespons Covid-19 (Gugus Tugas Percepatan Penanganan Covid-19 2020).

\section{Komunikasi Krisis}

Krisis bisa mencakup kekurangan dan ketidakpastian informasi sehingga dibutuhkan peran PR sebagai aktivitas fungsi manajemen komunikasi. Untuk mengatasi ketidakpastian informasi tersebut, PR bertanggung jawab dalam menyediakan saluran komunikasi secara proaktif yang dapat menyebarkan informasi yang benar kepada publik. Salah satu upaya menyediakan informasi secara reguler adalah menyediakan informasi yang setiap saat dapat diakses media massa. Komunikasi yang tertutup dapat menyebabkan kesalahan persepsi dan memunculkan isu-isu yang meluas serta bersifat negatif bagi perusahaan. Strategi komunikasi dalam krisis biasa disebut komunikasi krisis yang merupakan bagian dari strategi manajemen krisis (Kriyantono 2018). Menurut Sellnow dan Seeger (2013), komunikasi krisis dapat dipahami sebagai proses berkelanjutan untuk menciptakan makna bersama baik dalam maupun antar kelompok, komunitas, individu, serta lembaga dalam konteks ekologis krisis dengan tujuan mempersiapkan, mengurangi, membatasi, dan menanggapi ancaman serta bahaya. Teori komunikasi krisis mempersoalkan pesan-pesan dan proses konstruksi makna dalam semua bentuk interaksi dan koordinasi manusia yang mengelilingi peristiwa-peristiwa yang mengancam dan ketidakpastian tinggi ini.

Kriyantono (2018) dan Nova (2017) memaparkan strategi dan prinsip yang dapat digunakan oleh PR dalam menghadapi krisis yakni: (1) membangun tim krisis dengan anggota lintas bidang selaras dengan pembagian kerja dari hasil perencanaan krisis agar lebih terkontrol dan terarah; (2) mengelola informasi secara cepat, tepat, jujur, sesuai fakta, diperbarui secara berkala, tetap menjaga reputasi instansinya, memperlihatkan rasa empati dan menggunakan sistem komunikasi satu pintu; serta (3) menggunakan beragam media secara bersamaan sehingga informasi dimungkinkan sampai ke penduduk dengan segmen yang berbeda-beda; dan (4) memelihara hubungan yang baik dengan publiknya. Pemerintahan Kabupaten Bogor menanganinya dengan membentuk tim krisis berupa Gugus Tugas Percepatan Penanganan Covid-19 Kabupaten Bogor serta memanfaatkan media cyber untuk diseminasi informasi kesehatan Covid-19 sebagai respons pada krisis pandemi Covid-19.

\section{Komunikasi krisis Covid-19 Indonesia}

Gugus Percepatan Penagnan Covid-19 Indonesia mengeluarkan dokumen Protokol Percepatan Penanganan Pandemi Covid-19 yang didalamnya mencangkup koordinasi dan komunikasi publik. Komunikasi publik penting dilakukan demi membangun persepsi penduduk yang positif terhadap kesiapan dan keseriusan penanganan pemerintah serta menghindari terjadinya kepanikan masyarakat. Gugus tugas juga menghimbau semua pimpinan daerah baik tingkat provinsi maupun kabupaten/kota untuk menciptakan produk komunikasi dan menyebarkan informasi mengenai: (1) penjelasan dasar mengenai apa Covid-19; (2) penjelasan pencegahan wabah Covid-19; (3) himbauan deteksi dini mandiri Covid-19; (4) penjelasan dan kriteria PDP (Pasien Dalam Pengawasan) dan ODP (Orang Dalam Pemantauan); (5) menyusun panduan penanganan dari PDP dan ODP; (6) menyusun Panduan Karantina Mandiri dan Karantina Komunal; (7) informasi Rumah Sakit Rujukan COVID-19. Hal tersebut dilakukan dengan tetap menjaga kerahasiaan identitas pasien. Informasi-informasi tersebut patut merujuk dan mendapat persetujuan dari Kementerian Kesehatan (Pemerintah Pusat) demi menghindari perbedaan informasi di penduduk. Pemerintah Daerah diperbolehkan menciptakan produk komunikasi sesuai dengan data dan kebutuhan daerah masing-masing dengan memastikan jalur informasi dua arah berlaku dan disepakati oleh seluruh pihak. Sistem komunikasi harus dibentuk untuk memastikan komunikasi terjadi dengan lancar.

\section{Efektivitas Strategi Cyber GPR}

Strategi merupakan metode pemecahan masalah untuk mencapai tujuan. Di samping krisis pandemi Covid-19 dengan kecepatan penyebaran yang masif, informasi kesehatan Covid-19 harus tetap terdedah di kalangan masyarakat. Pengukuran terhadap program PR dalam penelitian ini penggunaan strategi cyber PR dalam diseminasi informasi Covid-19 sebagai bentuk komunikasi krisis dapat dianalisis pada tahapan dan level yang digambarkan pada Gambar 1. 


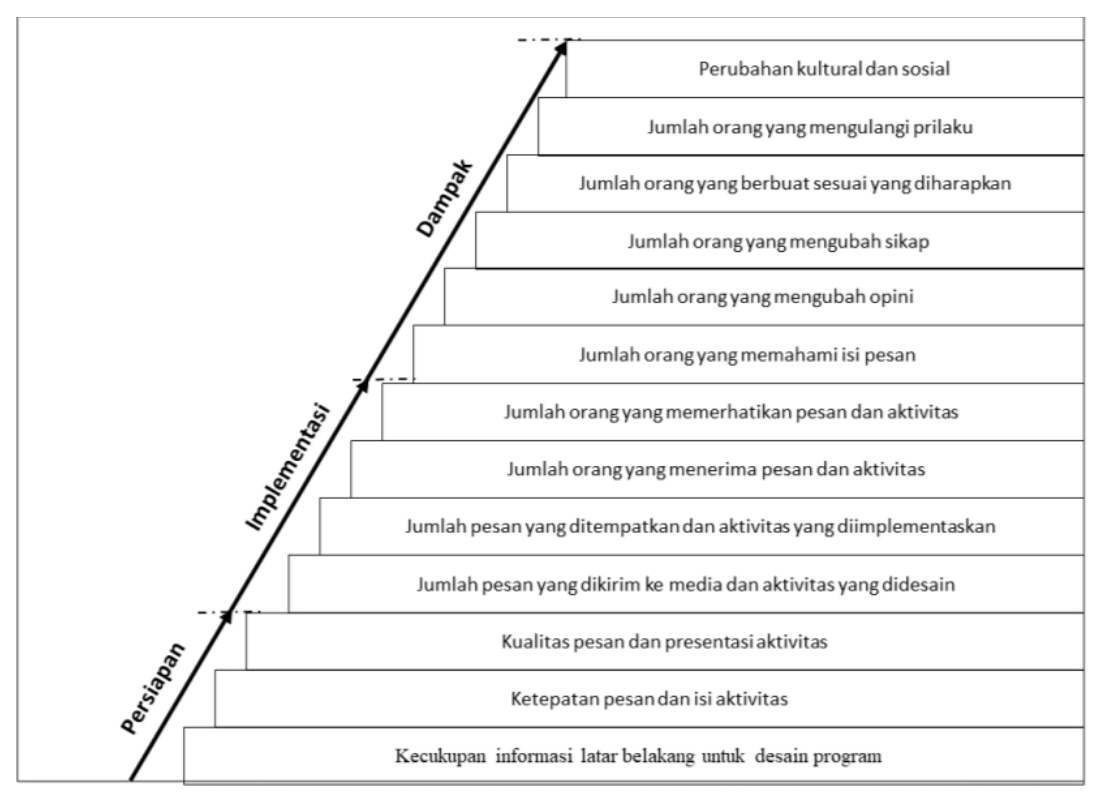

Gambar 1 Tahap dan level evaluasi program PR

Sumber: Cutlip et al. (2006)

Penelitian ini akan meneliti pada tahap dampak pada level perubahan sikap penduduk yang terdedah informasi berupa tujuh informasi pokok yang harus didiseminasikan oleh pemerintah daerah seperti yang dicantumkan pada protokol komunikasi publik Covid-19 oleh Gugus Tugas Covid-19 Indonesia. Sejalan dengan efek yang dihasilkan dari komunikasi, ranah perubahan sikap dapat dianalisis dari segi kognitif, afektif, dan konatif. Kognitif dimaknai sebagai pengetahuan dan kepercayaan, afeksi merupakan perasaan, dan konatif perubahan kecenderungan berperilaku (McQuails 2010; Crespi 1997). Pada penelitian ini, aspek kognitif dilihat dari persepsi responden mengenai seberapa pentingnya mengetaui informasi terkait yang terdapat dalam 7 poin protokol komunikasi publik krisis Covid-19.

\section{Kerangka Pemikiran}

PR adalah sebuah fungsi manajemen terencana untuk membangun hubungan baik, internal maupun eksternal, demi mencapai tujuan spesifik yang mampu memberikan manfaat kepada kedua belah pihak baik dalam bentuk kerja sama, peningkatan produktivitas serta efisiensi perusahaan. Salah satu bentuk dari PR adalah government public relations (GPR). GPR merupakan PR non komersial yang dijalankan oleh lembaga pemerintahan yang menekankan pada pelayanan penduduk dalam bidang komunikasi yang bersifat responsif serta publisitas utamanya merupakan informasi-informasi publik. Strategi dalam dunia PR diartikan sebagai konsep, pendekatan, atau rencana umum untuk program yang didesain guna mencapai tujuan. Strategi komunikasi PR dimaknai sebagai isi pesan apa yang harus disampaikan untuk mencapai hasil seperti dinyatakan dalam sasaran program (Cutlip et al. 2006) Strategi komunikasi PR akan mendukung program aksi dengan cara memberi informasi pada publik, membujuk publik untuk mendukung dan menerima tindakan tersebut, serta memberi petunjuk kepada publik mengenai cara menerjemahkan niat ke dalam aksi. Mengetahui publik sasaran ini akan berguna untuk menyusun strategi komunikasi yang tepat. Salah satu strategi yang dapat digunakan yakni Cyber PR. Cyber PR adalah inisiatif PR dengan menggunakan internet sebagai media publisitas. Potensi berkomunikasi yang dapat dilakukan lebih luas seperti membentuk hubungan one-to-one, komunikasi massa, pemasaran yang dapat dilakukan secara konstan, respons cepat, menjangkau pasar global, interaktif, dua arah, serta hemat. Kemudahan ini menjadi penggunaan media baru sangat tepat digunakan sebagai strategi government public relation untuk diseminasi informasi pembangunan masyarakat.

Salah satu fungsi dari komunikasi krisis di antaranya adalah crisis response yang didalamnya terdapat diseminasi informasi. Kriyantono (2018) dan Nova (2017) memaparkan strategi dan prinsip yang dapat digunakan oleh PR dalam menghadapi krisis yakni: (1) Membangun tim krisis dengan anggota lintas bidang selaras dengan pembagian kerja dari hasil perencanaan krisis agar lebih terkontrol dan terarah; 
(2) Mengelola informasi secara cepat, tepat, jujur, sesuai fakta, diperbarui secara berkala, tetap menjaga reputasi instansinya, memperlihatkan rasa empati dan menggunakan sistem komunikasi satu pintu; serta (3) Menggunakan beragam media secara bersamaan sehingga informasi dimungkinkan sampai ke penduduk dengan segmen yang berbeda-beda; dan (4) Memelihara hubungan yang baik dengan publiknya. Pemerintahan Kabupaten Bogor menanganinya dengan membentuk tim krisis berupa Gugus Tugas Percepatan Penanganan Covid-19 Kabupaten Bogor serta memanfaatkan media cyber untuk diseminasi informasi kesehatan Covid-19 sebagai respons pada krisis pandemi Covid-19.

Terdapat dua elemen utama yang mempengaruhi pemanfaatan media oleh publik yakni elemen struktur sosial dan media (McQuails 2010). Struktur sosial adalah fakta sosial dari pengguna seperti pendidikan, pendapatan, jenis kelamin, serta jenis pekerjaan yang lebih lanjut akan dijelaskan dalam karakteristik individu. Analisis media dilihat melalui pandangan masyarakat Kabupaten Bogor yang terdedah informasi kesehatan Covid-19 dari strategi cyber GPR dengan menggunakan instrumen Webqual 4.0 yang diadaptasi. Instrumen ini akan membantu menganalisis pandangan penduduk terhadap dimensidimensi pada media cyber GPR yang digunakan. Sejalan dengan apa yang dinyatakan Cutlip et al. (2006) bahwa diperlukan penggunaan media yang paling dekat dengan pandangan audiens untuk mengurangi diskrepansi posisi di antara keduanya.

Efektivitas strategi PR dianalisis berdasarkan tahap dan level evaluasi program PR. Tahapan terdiri persiapan, implementasi, dan dampak yang masing-masing dilihat dari berbagai level (Cutlip et al. 2006). Tahapan persiapan akan digali lebih lanjut melalui wawancara kepada pihak-pihak yang berperan dalam pengelolaan informasi kesehatan Gugus Tugas Percepatan Penanganan Covid-19 Kabupaten Bogor. Tahap implementasi akan dianalisis pada level jumlah orang yang menerima dan memperhatikan pesan dan aktivitas. Analisis ini dilihat pada tingkat diseminasi informasi kesehatan Covid-19 penduduk Kabupaten Bogor. Tingkat diseminasi informasi dapat dilihat melalui keterdedahan penduduk akan informasi tersebut yang disebarkan melalui media cyber GPR. Menurut Rodman (2006), yang dimaksud dengan keterdedahan adalah proses pencarian pesan oleh individu untuk mencari pesan yang dapat membantunya dalam menentukan sikap. Indikator yang digunakan untuk mengukur keterdedahan terhadap media dapat dilihat dari frekuensi dan intensitas memanfaatkan media dalam pencarian informasi.

Menghubungkan karakteristik individu dan penilaian terhadap media cyber dengan tingkat diseminasi informasi akan membantu untuk mengenali lebih dalam audien sasaran. Ini berguna pula untuk mengetahui cara yang tepat untuk diseminasi informasi kesehatan sesuai dengan apa yang mereka butuhkah dan gunakan. Hal ini akan berguna untuk menyusun strategi komunikasi yang tepat sebagai tindak evaluasi lebih lanjut. Sehingga PR dapat mengembangkan isi pesan, memilih pola komunikasi, dan media yang sesuai dengan audien agar tercipta komunikasi yang efektif dan efisien untuk menyampaikan pesan yang dimaksud. Pemahaman yang salah terhadap pola pikir publik hanya akan menyebabkan informasi yang disalurkan tidak bisa bertahan lama (Wasesa 2006).

Tahap dampak dilihat pada level perubahan sikap penduduk yang terdedah informasi kesehatan Covid19. Informasi ini akan berfokus pada tujuh informasi pokok yang harus didiseminasikan oleh pemerintah daerah seperti yang dicantumkan pada protokol komunikasi publik Covid-19 oleh Gugus Tugas Covid19 Indonesia. Menurut Hartono (2016), sikap adalah reaksi tertutup seseorang akan rangsangan atau obyek, baik yang bersifat internal maupun eksternal, yang sudah melibatkan faktor pendapat dan emosi yang bersangkutan (senang - tidak senang, setuju - tidak setuju, baik- tidak baik) sehingga penampakannya tidak terlihat secara langsung. Tede (2012) dan Andika (2008) membuktikan bahwa semakin tinggi frekuensi dan intensitas penggunaan media, semakin besar kemungkinan khalayak untuk mendapatkan berbagai informasi. Sejalan dengan efek yang dihasilkan dari komunikasi, ranah perubahan sikap dapat dianalisis dari segi kognitif, afektif, dan konatif. Kognitif dimaknai sebagai pengetahuan dan kepercayaan, afeksi merupakan perasaan, dan konatif perubahan kecenderungan berperilaku (McQuails 2010; Crespi 1997).

Keragaman media cyber yang digunakan akan menghasilkan tingkatan efektivitas yang berbeda pula. Cutlip et al. (2006) menyatakan bahwa teknik komunikasi yang berbeda akan efektif pada poin yang berbeda dan dengan cara yang berbeda. Penting untuk komunikator mengetahui apa teknik dan media 
yang akan digunakan pada tahap yang berbeda dan mengetahui bagaimana cara memobilisasi pengaruh ini secara efektif.

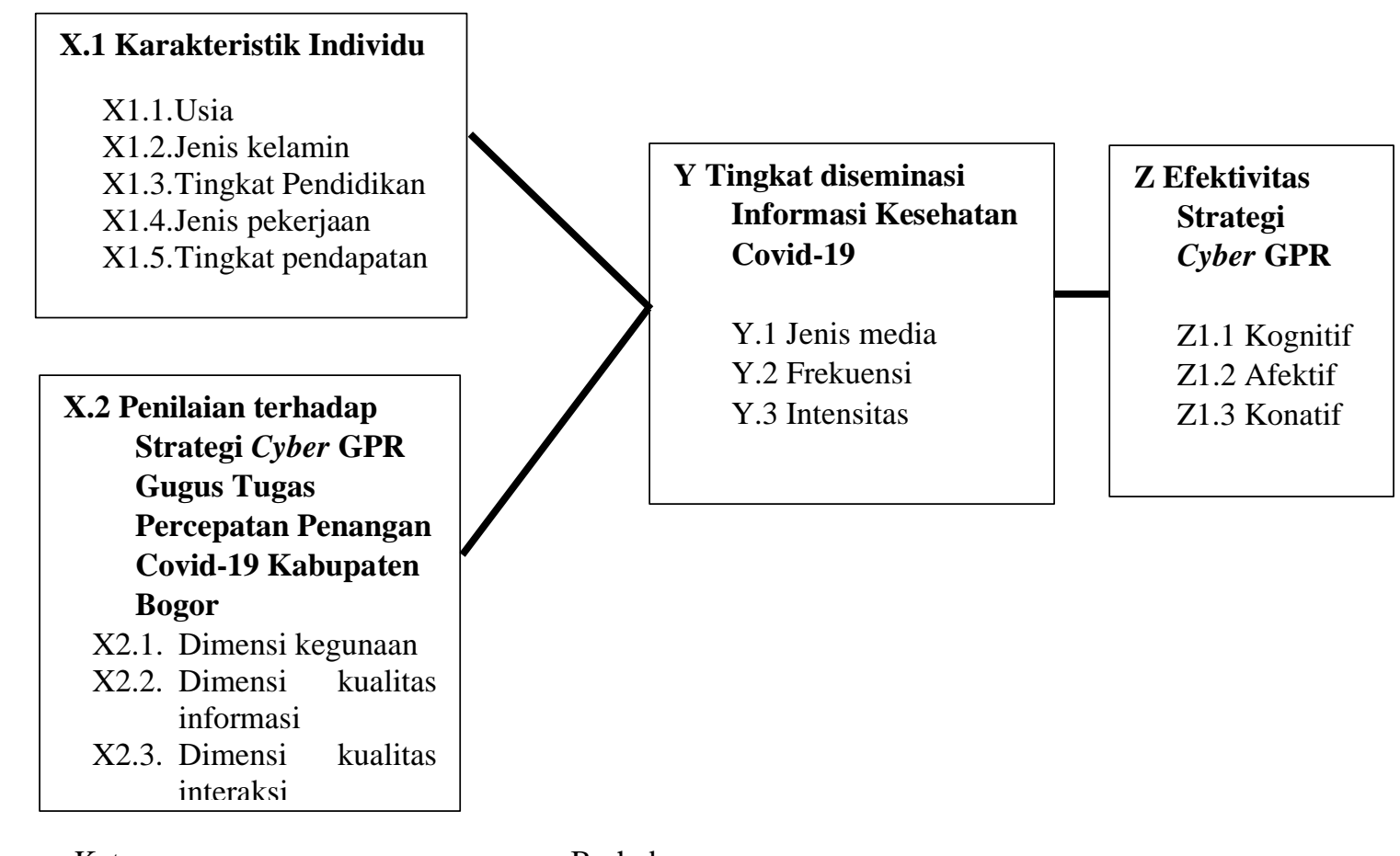

\section{Keterangan: \\ Gambar 2 Kerangka pemikiran}

Berhubungan

Berdasarkan kerangka penelitian diatas, maka hipotesis pada penelitian ini adalah diduga terdapat hubungan peran pemuda dalam pemberdayaan masyarakat dengan taraf hidup pada masa pandemi Covid-19

1. Diduga terdapat hubungan antara karakteristik individu dengan tingkat diseminasi informasi kesehatan Covid-19.

2. Diduga terdapat hubungan antara penilaian terhadap strategi cyber GPR terhadap tingkat diseminasi informasi kesehatan Covid-19.

3. Diduga terdapat hubungan antara tingkat diseminasi informasi kesehatan dengan efektivitas strategi cyber GPR Gugus Tugas Penanganan Percepatan Covid-19.

\section{METODE PENELITIAN}

Desain penelitian ini menggunakan desain penelitian eksplanasi yang bertujuan untuk menguji hubungan antar variabel yang dihipotesiskan (Singarimbun dan Effendi 2012). Hipotesis menggambarkan hubungan antara dua atau lebih variabel. Desain ini dimaksudkan untuk menjelaskan suatu generalisasi sampel terhadap variabel yang lain. Mulyadi (2011) menyatakan bahwa penelitian eksplanasi memiliki kredibilitas untuk mengukur, menguji hubungan sebab akibat dari dua atau lebih variabel dengan menggunakan analisis statistik inferensial (induktif).

Penelitian ini menggunakan metode kuantitatif yang didukung dengan data kualitatif. Pendekatan kuantitatif dilaksanakan dengan menggunakan metode survei yang memanfaatkan kuesioner sebagai instrumen dalam mengumpulkan informasi. Atas dasar pertimbangan situasi pandemi Covid-19 yang semakin tinggi di lokasi penelitian, survei dilaksanakan dengan menyebarkan kuesioner secara online menggunakan ipb.link yang diintegrasikan dengan google form melalui media sosial. Media sosial yang digunakan merupakan media sosial peneliti dan GPR pemerintah Kabupaten Bogor. Data kuantitatif digunakan untuk analisis deskriptif mengenai karakteristik individu responden, penilaian terhadap strategi cyber GPR, tingkat diseminasi, serta efektivitas strategi cyber GPR. Jenis data ini juga digunakan untuk analisis korelasional antara karakteristik individu responden dengan tingkat diseminasi, penilaian terhadap strategi cyber GPR dengan tingkat diseminasi, serta tingkat diseminasi dengan efektivitas strategi cyber GPR. 
Data kualitatif didapatkan untuk menggali informasi yang sifatnya lebih mendalam serta untuk memperjelas gambaran tentang keadaan sosial yang diperoleh melalui metode kuantitatif. Data ini diperoleh dengan wawancara mendalam yang dilakukan kepada responden serta informan. Data ini didapatkan dengan melakukan wawancara mendalam kepada informan baik secara langsung (memperhatikan protokol Covid-19) maupun secara online. Wawancara dilakukan dengan menggunakan panduan pertanyaan. Hasil wawancara secara tatap muka direkam menggunakan smartphone dan laptop recorder. Penelitian dengan dua pendekatan ini dapat saling memperkuat dan saling melengkapi sehingga dicapai hasil penelitian yang tidak hanya objektif, terstruktur dan terukur namun dapat dicapai juga hasil penelitian yang mendalam dan faktual (Mulyadi 2011).

\section{Lokasi dan Waktu Penelitian}

Penelitian dilaksanakan di Kabupaten Bogor. Lokasi ini dipilih dengan pertimbangan sebagai berikut:

1. Pelanggaran PSBB dan penambahan jumlah penduduk Kabupaten Bogor yang terinfeksi masih terus terjadi. Meskipun, beragam media cyber yang digunakan oleh Gugus Tugas Covid-19 Kabupaten Bogor dalam diseminasi informasi kesehatan Covid-19.

2. Keragaman media cyber yang digunakan oleh Gugus Tugas Covid-19 Kabupaten Bogor dalam diseminasi informasi kesehatan Covid-19.

3. Kondisi pandemi Covid-19 selama masa penelitian.

Maka dari itu, kasus ini menarik untuk diteliti di Kabupaten Bogor. Kegiatan penelitian dilaksanakan dalam jangka waktu 14 bulan. Rangkaian kegiatan terhitung mulai bulan Mei 2020 sampai dengan September 2021. Kegiatan penelitian meliputi penyusunan proposal skripsi, kolokium, perbaikan proposal, uji coba kuesioner, revisi kuesioner, pengambilan data lapangan, pengolahan dan analisis, penulisan draf skripsi, uji petik, sidang skripsi, dan terakhir perbaikan laporan skripsi.

\section{Teknik Penentuan Responden dan Informan}

Pengambilan responden pada penelitian ini menggunakan metode non-probability sampling. Metode ini dilaksanakan berdasarkan pertimbangan-pertimbangan tertentu. Contoh penerapan dari sampling ini adalah purposive sampling dan quota sampling (Singarimbun dan Effendi 2012). Terdapat penerapan baru dari metode sampling non-probability ini yang disebut dengan voluntary sampling (Murairwa 2015). Sampel dipilih dari calon responden yang bersedia dan memenuhi syarat untuk mengikuti survei. Metode ini paling banyak digunakan dalam jajak pendapat (Hayati 2019). Keberhasilan atau kegagalan dari desain sampling ini bergantung pada dua aspek, yakni publikasi maksud dan tujuan mengadakan survei dan pilot sampling untuk menentukan kesiapan calon responden untuk berpartisipasi dalam survei.

Publikasi maksud dan tujuan survei online ini dilakukan pada narasi yang dituliskan di unggahan penyebaran link melalui media sosial Instagram @kabupaten.bogor, Twitter @bogorkab, Facebook @bogorkab, serta media sosial peneliti. Penyebaran link melalui berbagai media ini juga dilakukan demi menghindari terpusatnya data pada penduduk dari sebagian kecil wilayah di Kabupaten Bogor saja.

Pilot sampling yang dimaksud adalah membuat stratifikasi populasi target, memperkirakan tingkat respons, serta menguji kualitas respons. Stratifikasi populasi dibagi menjadi dua strata utama yakni volunteer dan non-volunteer. Volunteer yang dimaksud adalah pengguna media sosial terkait yang mendapatakn informasi mengenai survey online dan bersedia mengisi kuesioner. Sedangkan nonvolunter adalah mereka yang mendapat informasi mengenai survei namun tidak mengisi. Volunteer mungkin menuhi atau tidak memenuhi kriteria yang dibutuhkan. Volunteer yang memenuhi kriteria dipilih sebagai sampel akhir. Pada penelitian ini, ditemukan sebanyak 86 volunteer yang bersedia mengisi kuesioner online. Dari 86 tersebut, terdapat 13 responden yang berdomisili di Kota Bogor. Dilansir dalam BPS Kabupaten Bogor (2020), penduduk adalah semua orang yang berdomisili di wilayah geografis Republik Indonesia selama 6 bulan atau lebih dan atau mereka yang berdomisili kurang dari 6 bulan tetapi bertujuan untuk menetap. Maka dari itu, didapat sebanyak 73 responden sampel akhir penduduk Kabupaten Bogor. Dari 73 responden tersebut, terdapat 21 responden pengguna media utama website bogorkab.go.id, 30 Instagram @kabupatenbogor, 12 Twitter @kabupatenbogor, serta 10 responden Facebook @ bogorkab. 
Pemilihan informan dalam penelitian ini dilakukan secara sengaja (purposive) dengan mempertimbangkan status dan peran, jaringan sosial, serta kompetensi informan potensial yang diteliti (Creswell 2007). Informan dalam kasus ini adalah Kepala Bidang Aplikasi dan Informatika mengenai strategi komunikasi informasi kesehatan Covid-19 secara keseluruhan, tim media center sebanyak 2 orang serta Kasie Integrasi dan Interoperabilitias Aplikasi mengenai media sosial Instagram, Twitter dan Facebook, Bidang Pengembangan Aplikasi dan Data sebanyak 1 orang mengenai website covid19.bogorkab.go.id, Bidang Pengelolaan Informasi dan Komunikasi Publik sebanyak 2 orang mengenai publikasi informasi, Tim branding sebanyak 5 orang mengenai lebih dalam tentang disemiansi informasi kesehatan Covid-19 melalui media sosial serta desian tampilan konten, Kasie Komunikasi Publik selaku humas mengenai peran humas dan diskominfo, serta 35 responden yang bersedia untuk dihubungi lebih lanjut.

\section{Teknik Pengumpulan Data}

Sumber data yang digunakan dalam penelitian ini adalah data primer dan data sekunder. Data primer yang diperoleh dengan menggunakan instrumen kuesioner yang disebarkan secara online dan wawancara mendalam. Wawancara dilakukan baik secara online maupun tatap muka dengan tetap memperhatikan protokol Covid-19. Colton dan Convert (2007) berpendapat bahwa salah satu alat mengumpulkan data dalam pendekatan kualitatif biasanya adalah panduan wawancara yang berisi daftar pertanyaan yang bersifat terbuka. Pertanyaan tambahan harus dimunculkan selama proses tanya jawab terjadi dengan tetap berpedoman pada panduan wawancara yang telah dibuat. Data sekunder diperoleh melalui data kependudukan Kabupaten Bogor, data pengakses website Covid-19.bogorkab.go.id, data pengakses media sosial yang terintegrasi dengan website tersebut (Instagram @ kabupatenbogor, Twitter @bogorkab,Facebook@bogorkab), serta berbagai literatur terkait dengan penelitian.

\section{Uji Validitas dan Uji Reliabilitas}

Uji validitas dilakukan untuk mengetahui sejauh mana alat pengukur yang digunakan sesuai untuk mengukur apa yang ingin diukur (Nurdin dan Hartati 2019). Sebelum melakukan penelitian di lapang, kuesioner diuji validitas dan reliabilitasnya kepada 10 orang di luar responden yang dipilih untuk menjadi data primer dalam penelitian ini. 10 responden ini didapat dari data penjajakan online yang telah dilakukan sebelumnya. Penjajakan online ini dilakukan dalam bentuk survei singkat. Survei singkat dilakukan dengan menyebarkan link pada media sosial peneliti (Instagram, Facebook, Twitter, Line, Whatsapp), penyebaran pada akun rekan-rekan di berbagai daerah Kabupaten Bogor, serta dengan cara personal chat kepada 'penyuka' akun Facebook @bogorkab. Survei ini bertujuan untuk mengetahui pengetahuan penduduk Kabupaten Bogor mengenai website Covid-19.bogorkab.go.id, media cyber apa saja yang digunakannya untuk mendapatkan informasi seputar Covid-19 Kabupaten Bogor, serta nomor telefon atau identitas kontak lain jika bersedia dihubungi lebih lanjut mengenai penelitian ini. Hasil survei mendapat sebanyak 37 responden dengan 27 di antaranya bersedia untuk dihubungi lebih lanjut. Dari 27 responden, sebanyak 9 responden mendapat informasi melalui website, 14 Instagram, 3 Twitter, dan 1 Facebook. Hasil ini menjadi dasar peneliti untuk memilih 10 responden sebagai berikut: 3 responden yang memilih website, 3 Instagram, 3 Twitter, dan 1 Facebook. Sebanyak 17 responden lainnya dihubungi kembali untuk ditanyakan kesediaannya berpartisipasi pada pengisian kuesioner online penelitian sebenarnya.

Pengujian reliabilitas dilakukan dengan metode Alpha Cronbach $(\alpha)$. Suatu variabel penelitian dinyatakan reliabel apabila memiliki nilai koefisien Cronbach's Alpha senilai > 0.60 (Babbie 2014). Uji reliabilitas digunakan untuk menunjukkan sejauh mana suatu alat ukur dapat dipercaya atau dapat diandalkan apabila digunakan lebih dari satu kali untuk mengukur gejala yang sama dan hasil pengukuran yang diperoleh relatif konsisten (Nurdin dan Hartati 2019). Uji reliabilitas dilakukan dalam penelitian ini menggunakan software IBM SPSS Statistics.

\section{Teknik Pengolahan dan Analisis Data}

Data kuantitatif didapatkan dari hasil pengisian kuesioner oleh responden terkait dengan variabel yang diteliti. Data kuantitatif diolah menggunakan aplikasi SPSS. Aplikasi ini digunakan untuk analisis deskriptif tabel frekuensi serta uji statistik korelasi Rank Spearman untuk variabel berskala ordinal dengan ordinal dan uji korelasi Chi square untuk variabel berskala nominal dengan ordinal. Analisis korelasi dilakukan untuk melihat tingkat kekuatan, arah, serta signifikansi hubungan antar variabel. 
Kekuatan hubungan antar variabel dilihat dari nilai koefisien korelasi dari hasil olahan data SPSS dengan ketentuan

1. Nilai koefisien korelasi sebesar $0.00-0.25=$ hubungan sangat lemah

2. Nilai koefisien korelasi sebesar $0.26-0.50=$ hubungan cukup

3. Nilai koefisien korelasi sebesar $0.51-0.75=$ hubungan kuat

4. Nilai koefisien korelasi sebesar $0.76-0.99=$ hubungan sangat kuat

5. Nilai koefisien korelasi sebesar $1.00=$ hubungan sempurna

Arah korelasi dianalisis dengan memperhatikan nilai koefisien korelasi yang berkisar antara +1 sampai -1. Jika bernilai positif, maka hubungan kedua variabel searah dan sebaliknya. Signifikansi hubungan antar variabel dilihat dari nilai Sig. (2-tailed). Hubungan dikatakan signifikan jika nilai Sig. (2-tailed) < dari 0.05 atau 0.01. Sedangkan hubungan tidak signifikan jika nilai Sig. (2-tailed) > dari 0.05 atau 0,01 (spssindonesia.com 2017).

Hasil olah data menggunakan Chi square Test dianalisis dengan membandingkan antara nilai Asym.Sig. dengan batas kritis yakni 0.05. Jika nilai Asym.Sig. (2-sided) < 0,05, maka H0 ditolak dan Ha diterima. Sedangkan jika nilai Asymp.Sig (2-sided) > 0,05, maka H0 diterima dan Ha ditolak. (spssindonesia.com 2015). Analisis deskriptif dilakukan melalui statistika deskriptif, yaitu mendeskripsikan data yang telah terkumpul secara statistik. Analisis data deskriptif dilakukan dengan menyajikan data melalui tabulasi silang.

Analisis data pada penelitian kualitatif adalah suatu proses pengolahan data mentah berupa penuturan, perbuatan, catatan lapangan dan bahan-bahan tertulis yang lain yang memungkinkan peneliti menemukan hal-hal yang sesuai dengan apa yang diteliti. Data kualitatif didapatkan melalui wawancara mendalam kepada informan. Selain itu, wawancara mendalam juga dilakukan kepada informan untuk dapat melengkapi data primer yang didapatkan dan kepada responden yang bersedia untuk dihubungi lebih lanjut mengenai penelitian ini. Data kualitatif dianalisis melalui tiga tahap yaitu reduksi data, penyajian data, dan verifikasi. Reduksi data dimulai dari proses pemilihan, penyederhanaan, abstraksi, hingga transformasi data hasil wawancara mendalam dan studi dokumen. Tujuan dari reduksi data ini adalah untuk mempertajam, menggolongkan, mengarahkan, dan membuang data yang tidak perlu. Berikutnya adalah penyajian data dengan menyusun informasi dan data yang diperoleh menjadi serangkaian kata-kata yang mudah dibaca ke dalam sebuah laporan, dalam bentuk kutipan atau tipologi. Kemudian yang terakhir adalah verifikasi yaitu berupa penarikan kesimpulan dari hasil yang telah dipilah pada tahap reduksi. Seluruh data tersebut pada akhirnya dituliskan pada laporan skripsi (Sarwono 2006).

\section{HASIL DAN PEMBAHASAN}

\section{Hubungan karakteristik individu dengan tingkat diseminasi informasi kesehatan Covid-19}

McQuails (2010) menyatakan bahwa pemanfaatan media dibentuk oleh dua elemen utama yakni elemen struktur sosial dan struktur media. Struktur sosial adalah fakta sosial dari pengguna seperti pendidikan, pendapatan, jenis kelamin, serta jenis pekerjaan. Tingkat diseminasi informasi dapat dilihat melalui keterdedahan penduduk akan informasi tersebut yang disebarkan melalui media gugus tugas percepatan penanganan Covid-19 Kabupaten Bogor. Pada penelitian ini, elemen struktur sosial dianalisis dari karakteristik individu responden yang terdiri dari usia, jenis kelamin, tingkat pendidikan, jenis pekerjaan, serta tingkat pendapatan.

Hubungan antara karakteristik individu dengan tingkat diseminasi informasi kesehatan Covid-19 diuji dengan uji korelasi Rank Spearman dan Chi square. Variabel usia, tingkat pendapatan, tingkat pendidikan, dan tingkat pendapatan diuji dengan Rank Spearman. Sedangkan variabel jenis kelamin dan jenis pekerjaan diuji dengan Chi square.

\section{Hubungan Usia dengan Tingkat Diseminasi Informasi Kesehatan Covid-19}

Pengukuran hubungan antara variabel usia dengan tingkat diseminasi diukur dengan menggunakan uji korelasi Rank Spearman. Hasil pengukuran tertera pada Tabel 6 sebagai berikut. 
Tabel 6 Hasil uji korelasi antar usia dengan tingkat diseminasi informasi kesehatan Covid-19 berdasrakan media utama yang diakses

\begin{tabular}{lccc}
\hline \multirow{2}{*}{ Media } & \multicolumn{2}{c}{ Koefisien Korelasi Rank Spearman } \\
\cline { 2 - 4 } & \multicolumn{2}{c}{ Nilai } & \multicolumn{2}{c}{ Sig* } \\
\cline { 2 - 4 } Website & & 0,32 & 0,157 \\
Instagram & 0,202 & 0,285 \\
Twitter & & 0,134 & 0,678 \\
Facebook & 0 & 1 \\
\hline
\end{tabular}

Terdapat hubungan yang cukup tinggi antar usia dan tingkat diseminasi pengguna media utama website. Sedangkan pada media lainnya ditemukan hubungan yang sangat lemah. Ditemukannya hubungan yang positif membuktikan bahwa semakin tinggi kategori usia maka semakin tinggi tingkat diseminasi informasi kesehatan Covid-19. Namun, pada seluruh media hubungan ini tidak signifikan

Tabel 7 Persentase netizen menurut usia dan tingkat diseminasi website

\begin{tabular}{|c|c|c|c|c|c|}
\hline \multirow{2}{*}{ Usia } & \multicolumn{3}{|c|}{ Tingkat diseminasi website } & \multicolumn{2}{|c|}{ Total } \\
\hline & Rendah & Sedang & Tinggi & $\%$ & $\mathbf{n}$ \\
\hline Masa remaja akhir & 60,0 & 40,0 & 0,0 & 100,0 & 5 \\
\hline Masa dewasa awal & 71,4 & 28,6 & 0,0 & 100,0 & 7 \\
\hline Masa dewasa akhir & 66,7 & 33,3 & 0,0 & 100,0 & 3 \\
\hline Masa lansia awal & 100,0 & 0,0 & 0,0 & 100,0 & 2 \\
\hline Masa lansia akhir & 0,0 & 75,0 & 25,0 & 100,0 & 4 \\
\hline \multirow{2}{*}{ Total } & 57,1 & 38,1 & 0 & \multirow{2}{*}{100,0} & \multirow{2}{*}{21} \\
\hline & 12 & 8 & 1 & & \\
\hline
\end{tabular}

Hasil uji korelasi dengan menggunakan Rank Spearman menemukan nilai koefisien 0.320 dengan $P$ Value sebesar 0.157. Arti dari temuan ini adalah adanya hubungan yang cukup kuat antara usia dengan tingkat diseminasi informasi kesehatan Covid-19 website. Semakin tinggi usia maka semakin tinggi tingkat diseminasinya. Tabel 7 menunjukkan bahwa pada masa lansia akhir, seluruh responden memiliki tingkat diseminasi sedang (75.0\%) dan tinggi (25.0\%). Sedangkan pada masa remaja akhir, kategori usia paling rendah, para responden website memiliki tingkat diseminasi rendah $(60.0 \%)$ dan sedang $(40.0 \%)$. Nilai P value $>0.05$ membuktikan bahwa hubungan ini tidak signifikan.

Tingginya tingkat diseminasi pada responden masa lansia akhir disebabkan karena tanggung jawab pekerjaannya serta rasa tanggung jawabnya terhadap orang- orang di sekitarnya. "Tempat saya tuh agak kurang kesadarannya. Jadi informasi dari situs situs resmi dibutuhkan. Kadang kadang saya buat orang-orang sebelah, orang-orang terdekat" ( $\mathrm{R}$, responden masa lansia akhir dengan tingkat diseminasi sedang). IE, responden kategori usia masa lansia akhir dengan tingkat diseminasi tinggi menyatakan bahwa:

"Saya sehari-hari selalu memantau perkembangan Covid-19 di Kabupaten Bogor. Kebetulan juga saya bergerak di media online. Setiap saat pemberitaan itu pun saya harus tayangin sesuai dengan keadaan Kabupaten Bogor ini apakah menambah atau berkurang gitu"

Sedangkan, responden pada kategori usia masa remaja akhir membuka terkadang membuka website dikarenakan kebutuhan pengambilan data untuk tugas akademik. "Untuk tugas kadang-kadang dimintanya harus dari websitenya. Atau kalau lagi perlu perlu aja ga dibuka terus" (BPM, kategori usia masa remaja akhir dengan tingkat diseminasi rendah).

Tabel 8 Persentase netizen menurut usia dan tingkat diseminasi Instagram

\begin{tabular}{|c|c|c|c|c|c|}
\hline \multirow{2}{*}{ Usia } & \multicolumn{3}{|c|}{ Tingkat diseminasi Instagram } & \multicolumn{2}{|c|}{ Total } \\
\hline & Rendah & Sedang & Tinggi & n & $\%$ \\
\hline Masa remaja akhir & 73,3 & 26,7 & 0,0 & 100,0 & 15 \\
\hline Masa dewasa awal & 53,8 & 46,2 & 0,0 & 100,0 & 13 \\
\hline Masa dewasa akhir & 0,0 & 100,0 & 0,0 & 100,0 & 1 \\
\hline Masa lansia awal & 100,0 & 0,0 & 0,0 & 100,0 & 1 \\
\hline Total & 63,3 & 36,7 & 0,0 & 100,0 & 30 \\
\hline
\end{tabular}


Hasil uji korelasi dengan menggunakan Rank Spearman menemukan nilai koefisien 0.202. Arti dari temuan ini adalah adanya hubungan yang sangat lemah antara usia dengan tingkat diseminasi informasi kesehatan Covid-19. Semakin tinggi usia maka semakin tinggi tingkat diseminasinya.

Skor tingkat diseminasi informasi Covid-19 pada responden Instagram paling besar ada pada tingkat sedang. Mayoritas responden pengguna media Instagram berada pada masa remaja akhir. Akses Instagram yang sedang ini dikarenakan responden cenderung mendapat informasi jika lewat di timeline saja. "Karena ketika saya waktu luang membuka Instagram saya melihat informasi tersebut di timeline. Sehingga lama kelamaan saya jadi kebiasaan untuk cek ke Instagram @kabupaten.bogor tersebut" (REP, masa remaja akhir).

Dapat dilihat pada Tabel 8 bahwa persentase tingkat diseminasi sedang dari usia masa remaja akhir sampai masa dewasa akhir semakin meningkat. Penggunaan media sosial Instagram. Namun, pada kategori usia masa lansia awal, hanya ada satu responden yang memiliki tingkat diseminasi rendah. Temuan ini didukung dengan $P$ Value sebesar $0.678>0.05$ yang membuktikan bahwa hubungan yang terjadi tidak signifikan.

Tabel 9 Persentase netizen menurut usia dan tingkat diseminasi Twitter

\begin{tabular}{lllllll}
\hline \multirow{2}{*}{ Usia } & \multicolumn{2}{c}{ Tingkat diseminasi Twitter } & \multicolumn{2}{c}{ Total } \\
\cline { 2 - 5 } & Rendah & Sedang & Tinggi & \% & n \\
\hline Masa remaja akhir & 42,9 & 42,9 & 14,3 & 100,0 & 7 \\
Masa dewasa awal & 25,0 & 75,0 & 0,0 & 100,0 & 4 \\
\multicolumn{2}{l}{ Masa dewasa akhir } & 0,0 & 100,0 & 0,0 & 100,0 & 1 \\
\hline \multirow{2}{*}{ Total } & $\%$ & 33,3 & 58,3 & 8,3 & \multirow{2}{*}{100,0} & \multirow{2}{*}{12} \\
& $\mathrm{~N}$ & 4 & 7 & 1 & & \\
\hline
\end{tabular}

Hasil uji korelasi dengan menggunakan Rank Spearman menemukan nilai koefisien 0.134. Arti dari temuan ini adalah adanya hubungan yang sangat lemah antara usia dengan tingkat diseminasi informasi kesehatan Covid-19 Semakin tinggi usia maka semakin tinggi tingkat diseminasinya. Pada Tabel 50 dapat dilihat bahwa persentase tingkat diseminasi pada tingkat sedang semakin meningkat dari masa remaja akhir hingga masa dewasa akhir. Namun, masih ditemukan pula adanya 1 responden pada kategori masa remaja akhir yang memiliki tingkat diseminasi tinggi. $P$ Value sebesar $0.678>0.05$ membuktikan bahwa hubungan yang ada tidak signifikan.

Menurut BHN, responden pada kategori masa remaja akhir, diseminasi informasi kesehatan Covid-19 yang di dapat dari Twitter hanya ketika dirinya melihat timeline saja. "Kalo lewat timeline aja sih. Kalo lewat baru di klik dan melihat informasi lainnya dari akun tersebut". 
Tabel 10 Persentase netizen menurut usia dan tingkat diseminasi Facebook

\begin{tabular}{|c|c|c|c|c|c|}
\hline \multirow{2}{*}{ Usia } & \multicolumn{3}{|c|}{ Tingkat diseminasi Facebook } & \multicolumn{2}{|c|}{ Total } \\
\hline & Rendah & Sedang & Tinggi & $\%$ & $\mathbf{n}$ \\
\hline Masa dewasa awal & 20,0 & 60,0 & 20,0 & $\overline{100,0}$ & 5 \\
\hline Masa dewasa akhir & 0,0 & 100,0 & 0,0 & 100,0 & 3 \\
\hline Masa lansia awal & 50,0 & 0,0 & 50,0 & 100,0 & 2 \\
\hline Total & 20,0 & 60,0 & 20,0 & \multirow{2}{*}{100,0} & \multirow{2}{*}{10} \\
\hline $\mathrm{n}$ & 2 & 6 & 2 & & \\
\hline
\end{tabular}

Hasil uji koreasi Spearman menemukan tidak adanya hubungan atara usia dengan tingkat diseminasi responden pengguna media utama Facebook. Pada Tabel 10 dapat dilihat masing-masing kategori usia memiliki tingkat diseminasi yang beragam.

\section{Hubungan Tingkat Pendidikan dengan Tingkat Diseminasi Informasi Kesehatan Covid-19}

Pengukuran hubungan antara variabel tingkat pendidikan dengan tingkat diseminasi diukur dengan menggunakan uji korelasi Rank Spearman. Hasil pengukuran tertera pada Tabel 52 sebagai berikut.

Tabel 11 Hasil uji korelasi antara tingkat pendidikan dengan tingkat diseminasi informasi kesehatan Covid-19

\begin{tabular}{lccc}
\hline \multirow{2}{*}{ Media } & \multicolumn{2}{c}{ Koefisien Korelasi Rank Spearman } \\
\cline { 2 - 4 } & Nilai & \multicolumn{2}{c}{ Sig* } \\
\hline Website & 0,053 & 0,82 \\
Instagram & 0,153 & 0,403 \\
Twitter & 0,112 & 0,73 \\
Facebook & 0 & 1 \\
\hline
\end{tabular}

Terdapat hubungan yang lemah antara tingkat pendidikan dengan tingkat diseminasi informasi kesehatan pada seluruh media cyber. Ditemukannya hubungan yang positif membuktikan bahwa semakin tinggi tingkat pendidikan maka semakin tinggi tingkat diseminasi informasi kesehatan Covid19. Namun, pada seluruh media hubungan ini tidak signifikan.

Hubungan Jenis Kelamin dengan Tingkat Diseminasi Informasi Kesehatan Covid-19

Pengukuran hubungan antara variabel jenis kelamin dengan tingkat diseminasi diukur dengan menggunakan uji korelasi chi square. Hasil pengukuran tertera pada Tabel 53 sebagai berikut.

Tabel 12 Hasil uji korelasi antara jenis kelamin dengan tingkat diseminasi informasi kesehatan Covid-19

\begin{tabular}{lrr}
\hline \multirow{2}{*}{ Media } & \multicolumn{2}{c}{ Koefisien Korelasi Pearson Chi-Square } \\
\cline { 2 - 3 } & Nilai & Asymptotic Significance (2-sided) \\
\hline Website & 0,583 & 0,747 \\
Instagram & 0,142 & 0,706 \\
Twitter & 0,381 & 0,827 \\
Facebook & 0 & 0,372 \\
\hline
\end{tabular}

Berdasarkan Tabel 12, tidak ada hubungan antara jenis kelamin dengan tingkat diseminasi informasi kesehatan Covid-19. Hal ini dilihat dari nilai Chi square hitung pada seluruh media $<5,991$ dan nilai $\operatorname{sig}(2$-tailed) $>0.005$.

\section{Hubungan Jenis Pekerjaan dengan Tingkat Diseminasi Informasi Kesehatan Covid-19}

Pengukuran hubungan antara variabel jenis pekerjaan dengan tingkat diseminasi diukur dengan menggunakan uji korelasi chi square. Hasil pengukuran tertera pada Tabel 13 sebagai berikut. 
Tabel 13 Persentase netizen menurut jenis pekerjaan dan tingkat diseminasi website

\begin{tabular}{lrrrrrr}
\hline \multirow{2}{*}{ Jenis pekerjaan } & \multicolumn{3}{c}{ Tingkat Diseminasi } & \multicolumn{2}{c}{ Total } \\
\cline { 2 - 7 } & Rendah & Sedang & Tinggi & \% & n \\
\hline Wiraswasta & 33,3 & 66,7 & 0,0 & 100,0 & 3 \\
Pegawai negeri sipil & 50,0 & 50,0 & 0,0 & 100,0 & 2 \\
Karyawan Swasta & 66,7 & 33,3 & 0,0 & 100,0 & 6 \\
Mahasiswa & 71,4 & 28,6 & 0,0 & 100,0 & 7 \\
Lainnya & 33,3 & 33,3 & 33,3 & 100,0 & 3 \\
\hline \multirow{2}{*}{ Total } & $\%$ & 57,1 & 38,1 & 4,8 & \multirow{2}{*}{100,0} & 21 \\
& $\mathrm{n}$ & 12 & 8 & 1 & & \multirow{2}{*}{1} \\
\hline
\end{tabular}

Dapat dilihat bahwa hanya pada jenis pekerjaan wiraswasta mayoritas responden memiliki tingkat diseminasi sedang. Hal ini disebabkan situasi Covid-19 berkaitan dengan pekerjaan wiraswasta. R menyatakan bahwa:

"Sebenernya saya liatnya kadang kadang aja. Kebanyakan liat halaman depan baca baca berita aja sih buat di Kabupaten Bogor itu udah seperti apa. Kan ngaruh juga sama jualan. Terus penanganannya yang utama” (R).

Pada jenis pekerjaan selain wiraswasta, mayoritas responden memiliki tingkat diseminasi rendah. Berdasarkan hasil uji Chi square (Nilai Sig. (2-tailed) $0.444>0.05$ ) dan nilai Chi square hitung 7.896 $<15.511$ diperoleh bahwa jenis pekerjaan tidak memiliki hubungan dengan tingkat diseminasi informasi kesehatan. Dengan demikian, hasil uji mengungkapkan bahwa hipotesis penelitian pertama (H1) ditolak.

Tabel 14 Persentase netizen menurut jenis pekerjaan dan tingkat diseminasi Instagram

\begin{tabular}{|c|c|c|c|c|c|}
\hline \multirow{2}{*}{ Jenis pekerjaan } & \multicolumn{3}{|c|}{ Tingkat Diseminasi } & \multicolumn{2}{|c|}{ Total } \\
\hline & Rendah & Sedang & Tinggi & $\%$ & $\mathbf{n}$ \\
\hline Wiraswasta & 100,0 & 0,0 & 0,0 & 100,0 & 3 \\
\hline Karyawan Swasta & 55,6 & 44,4 & 0,0 & 100,0 & 9 \\
\hline Petani & 100,0 & 0,0 & 0,0 & 100,0 & 1 \\
\hline Mahasiswa & 75,0 & 25,0 & 0,0 & 100,0 & 8 \\
\hline Lainnya & 44,4 & 55,6 & 0,0 & 100,0 & 9 \\
\hline \multirow{2}{*}{ Total } & 63,3 & 36,7 & 0,0 & \multirow{2}{*}{100,0} & \multirow{2}{*}{30} \\
\hline & 19 & 11 & 0 & & \\
\hline
\end{tabular}

Berdasarkan hasil uji Chi square (Nilai Sig. (2-tailed) $0.354>0.05$ ) dan nilai Chi square hitung $4.402<$ 15.511 diperoleh bahwa jenis pekerjaan tidak memiliki hubungan dengan tingkat diseminasi informasi kesehatan. Mayoritas seluruh responden pengguna media utama Instagram memiliki tingkat diseminasi yang rendah. Kecenderungan responden dalam mengakses Instagram jika informasi tersebut lewat pada timeline nya saja dan dibuka ketika memiliki waktu luang atau kebutuhan tertentu. Seperti yang dinyatakan responden dengan profesi mahasisiwa dan guru honorer berikut: "Lewat timeline aja. Kalo ada berarti diliat, kalo gaada ya ga diliat. Tergantung kebutuhan" (NPK, mahasiswa)."Setiap hari ketika saya lagi istirahat saya buka Instagram buat liat di waktu luang, ada update-tan apa ini covid di kabupaten" (REC, guru honorer). 
Tabel 15 Persentase netizen menurut jenis pekerjaan dan tingkat diseminasi Twitter

\begin{tabular}{|c|c|c|c|c|c|c|}
\hline \multirow{2}{*}{$\begin{array}{c}\text { Jenis } \\
\text { pekerjaa }\end{array}$} & & \multicolumn{3}{|c|}{ Tingkat Diseminasi } & \multicolumn{2}{|c|}{ Total } \\
\hline & & Rendah & Sedang & Tinggi & $\%$ & $\mathrm{n}$ \\
\hline \multicolumn{2}{|c|}{ Pegawai negeri sipil } & 0,0 & 100,0 & 0,0 & 100,0 & 1 \\
\hline \multicolumn{2}{|c|}{ Karyawan Swasta } & 50,0 & 50,0 & 0,0 & 100,0 & 4 \\
\hline \multicolumn{2}{|c|}{ Mahasiswa } & 50,0 & 25,0 & 25,0 & 100,0 & 4 \\
\hline \multicolumn{2}{|l|}{ Lainnya } & 0,0 & 100,0 & 0,0 & 100,0 & 3 \\
\hline \multirow[t]{2}{*}{ Total } & $\%$ & 33,3 & 58,3 & 8,3 & \multirow{2}{*}{100,0} & \multirow{2}{*}{12} \\
\hline & $\mathrm{n}$ & 4 & 7 & 1 & & \\
\hline
\end{tabular}

Berdasarkan hasil uji Chi square (Nilai Sig. (2-tailed) $0.314>0.05$ ) dan nilai Chi square hitung 20.333> 12.59 diperoleh bahwa jenis pekerjaan memiliki hubungan dengan tingkat diseminasi informasi kesehatan.

Tabel 16 Persentase netizen menurut jenis pekerjaan dan tingkat diseminasi Facebook

\begin{tabular}{|c|c|c|c|c|c|}
\hline \multirow{2}{*}{ Jenis pekerjaan } & \multicolumn{3}{|c|}{ Tingkat Diseminasi } & \multicolumn{2}{|c|}{ Total } \\
\hline & Rendah & Sedang & Tinggi & $\%$ & $\mathbf{n}$ \\
\hline Wiraswasta & 33,3 & 66,7 & 0,0 & 100,0 & 3 \\
\hline Pegawai negeri sipil & 0,0 & 100,0 & 0,0 & 100,0 & 1 \\
\hline Lainnya & 16,7 & 50,0 & 33,3 & 100,0 & 6 \\
\hline \multirow{2}{*}{ Total } & 20,0 & 60,0 & 20,0 & \multirow{2}{*}{100,0} & \multirow{2}{*}{10} \\
\hline & 2 & 6 & 2 & & \\
\hline
\end{tabular}

Berdasarkan hasil uji Chi square (Nilai Sig. (2-tailed) $0.314>0.05$ ) dan nilai Chi square hitung $2.22<$ 9.49 diperoleh bahwa jenis pekerjaan tidak memiliki hubungan dengan tingkat diseminasi informasi kesehatan. Dapat dilihat pada Tabel 16 bahwa masing-masing jenis pekerjaan memiliki tingkat diseminasi yang berbeda.

\section{Hubungan Tingkat Pendapatan dengan Tingkat Diseminasi Informasi Kesehatan Covid-19}

Pengukuran hubungan antara variabel tingkat pendapatan dengan tingkat diseminasi diukur dengan menggunakan uji korelasi Rank Spearman.Tingkat pendapatan diukur berdasrakan UMK Kabupaten Bogor 2021. Hasil pengukuran tertera pada Tabel 17 sebagai berikut.

Tabel 17 Hasil uji korelasi antara tingkat pendapatan dengan tingkat diseminasi informasi kesehatan Covid-19

\begin{tabular}{lcrr}
\hline & \multirow{2}{*}{ Media } & \multicolumn{2}{c}{ Koefisien Korelasi Rank Spearman } \\
\cline { 2 - 4 } & \multicolumn{2}{c}{ Nilai } & Sig* \\
\hline Website & -0.184 & 0.425 \\
Instagram & -.0 .098 & 0.607 \\
Twitter & 0.029 & 0.928 \\
Facebook & -0.527 & 0.117 \\
\hline
\end{tabular}

Terdapat hubungan positif yang sangat lemah pada responden pengguna media utama Twitter. Hal ini membuktikan bahwa semakin tinggi tingkat pendapatan maka semakin tinggi tingkat diseminasi informasi Covid-19 pada Twitter. Sedangkan terdapat hubungan negatif dengan signifikansi yang beragam yang ditemukan pada responden pengguna media utama lainnya. 
Tabel 18 Persentase netizen menurut tingkat pendapatan dan tingkat diseminasi website

\begin{tabular}{|c|c|c|c|c|c|c|}
\hline \multirow{2}{*}{\multicolumn{2}{|c|}{$\begin{array}{c}\text { Tingkat pendapatan } \\
\text { berdasarkan UMK } \\
\text { Kabupaten Bogor } \\
2021\end{array}$}} & \multicolumn{3}{|c|}{ Tingkat diseminasi website } & \multicolumn{2}{|c|}{ Total } \\
\hline & & Rendah & Sedang & Tinggi & $\%$ & $\mathbf{n}$ \\
\hline \multirow{2}{*}{\multicolumn{2}{|c|}{$\begin{array}{l}\text { Di bawah } \\
\text { Di atas }\end{array}$}} & 52,9 & 41,2 & 5,9 & 100,0 & 17 \\
\hline & & 75,0 & 25,0 & 0,0 & 100,0 & 4 \\
\hline \multirow{2}{*}{ Total } & $\%$ & 57,1 & 38,1 & 4,8 & \multirow{2}{*}{100,0} & \multirow{2}{*}{21} \\
\hline & $\mathrm{n}$ & 12 & 8 & 1 & & \\
\hline
\end{tabular}

Pada Tabel 18 dapat dilihat bahwa baik responden dengan tingkat pendapatan di bawah maupun di atas UMK kabupaten Bogor memiliki tingkat diseminasi rendah (57.1\%). Mayoritas responden memiliki tingkat diseminasi sedang (60.0\%). Hasil uji korelasi menggunakan Rank Spearman ditemukan nilai koefisien korelasi sebesar -0.184 dengan $P$ value sebesar $0.425>0.05$. Arti dari hasil tersebut yaitu semakin meningkat variabel tingkat pendapatan, maka semakin menurun variabel tingkat diseminasi. Namun keterkaitan tersebut sangat lemah dan tidak signifikan.

Tabel 19 Persentase netizen menurut tingkat pendapatan dan tingkat diseminasi Instagram

\begin{tabular}{lcccccrr}
\hline $\begin{array}{c}\text { Tingkat pendapatan } \\
\text { berdasarkan UMK } \\
\text { Kabupaten Bogor 2021 }\end{array}$ & \multicolumn{2}{c}{ Tingkat diseminasi Instagram } & \multicolumn{2}{c}{ Total } & \\
\cline { 2 - 7 } & Rendah & Sedang & Tinggi & \% & n \\
\hline Di bawah & 60,0 & 40,0 & 0,0 & 100,0 & 20 \\
Di atas & 70,0 & 30,0 & 0,0 & 100,0 & 10 \\
\hline \multirow{2}{*}{ Total } & $\%$ & 63,3 & 36,7 & 0,0 & 100,0 & \multirow{2}{*}{30} \\
& $\mathrm{~N}$ & 19 & 11 & 0 & & \\
\hline
\end{tabular}

Pada media utama Instagram, mayoritas responden memiliki tingkat diseminasi rendah (63.3\%). Hasil uji korelasi menggunakan Rank Spearman ditemukan nilai koefisien korelasi sebesar -0.098 dengan $P$ value sebesar $0.607>0.05$. Arti dari hasil tersebut yaitu semakin meningkat variabel tingkat pendapatan, maka semakin menurun variabel tingkat diseminasi. Namun keterkaitan tersebut sangat lemah dan tidak signifikan.

Tabel 20 Persentase netizen menurut tingkat pendapatan dan tingkat diseminasi Twitter

\begin{tabular}{lcrrrrrr}
\hline $\begin{array}{c}\text { Tingkat pendapatan } \\
\text { berdasarkan UMK } \\
\text { Kabupaten Bogor }\end{array}$ & \multicolumn{2}{c}{ Tingkat diseminasi Twitter } & \multicolumn{2}{c}{ Total } & \\
\cline { 2 - 7 } \multicolumn{2}{c}{$\mathbf{2 0 2 1}$} & Rendah & Sedang & Tinggi & \% & n \\
\hline Di bawah & 37,5 & 50,0 & 12,5 & 100,0 & 8 \\
Di atas & 25,0 & 75,0 & 0,0 & 100,0 & 4 \\
\hline \multirow{2}{*}{ Total } & $\%$ & 33,3 & 58,3 & 8,3 & 100,0 & \multirow{2}{*}{12} \\
\hline
\end{tabular}

Pada media utama Twitter, mayoritas responden memiliki tingkat diseminasi sedang (58.3\%). Tingkat diseminasi yang sedang ini dikarenakan informasi kesehatan Covid-19 di dapat dari tweet yang lewat di timeline saja. "Kalau lewat di timeline aja sih soalnya follow kan terus pas lewat timeline dirasa menarik baru saya kunjungi pagenya (DU, responden dengan tingkat pendapatan di bawah UMK). Hal ini juga sama dengan yang dinyatakan $\mathrm{Y}$, responden dengan tingkat pendapatan di atas UMK. "Kalau lewat timeline aja paling"( $(\mathrm{Y})$.

Hasil uji korelasi menggunakan Rank Spearman ditemukan nilai koefisien korelasi sebesar 0.029 dengan $P$ value sebesar $0.928>0.05$. Arti dari hasil tersebut yaitu semakin meningkat variabel tingkat pendapatan, maka semakin meningkat pula variabel tingkat diseminasi namun keterkaitan tersebut sangat lemah dan tidak signifikan.

Tabel 21 Persentase netizen menurut tingkat pendapatan dan tingkat diseminasi Facebook 


\begin{tabular}{|c|c|c|c|c|c|c|}
\hline \multirow{2}{*}{\multicolumn{2}{|c|}{$\begin{array}{l}\text { Tingkat pendapatan } \\
\text { berdasarkan UMK } \\
\text { Kabupaten Bogor } 2021\end{array}$}} & \multicolumn{3}{|c|}{ Tingkat diseminasi Facebook } & \multicolumn{2}{|c|}{ Total } \\
\hline & & Rendah & Sedang & Tinggi & $\%$ & $\mathbf{n}$ \\
\hline \multirow{2}{*}{\multicolumn{2}{|c|}{$\begin{array}{l}\text { Di bawah } \\
\text { Di atas }\end{array}$}} & 11,1 & 66,7 & 22,2 & 100,0 & 9 \\
\hline & & 100,0 & 0,0 & 0,0 & 100,0 & 1 \\
\hline \multirow{2}{*}{ Total } & $\%$ & 20,0 & 60,0 & 20,0 & \multirow{2}{*}{100,0} & \multirow{2}{*}{10} \\
\hline & $\mathrm{n}$ & 2 & 6 & 2 & & \\
\hline
\end{tabular}

Hasil uji korelasi menggunakan Rank Spearman ditemukan nilai koefisien korelasi sebesar -0.527 dengan $P$ value sebesar $0.117>0.05$. Arti dari hasil tersebut yaitu semakin meningkat variabel tingkat pendapatan, maka semakin menurun variabel tingkat diseminasi namun keterkaitan tersebut sangat lemah dan tidak signifikan. Fakta di lapangan menemukan bahwa adanya kesamaan antara responden dengan tingkat pendapatan di bawah dan di atas UMK.

Mayoritas responden memiliki tingkat diseminasi sedang (60.0\%). Hal ini sama dengan media sosial Instagram dan Twitter bahwa responden umumnya mendapat informasi dari timeline. "Jujur awalnya ya karna kita udah ngelike jadi otomatis di beranda selalu ada. Tapi mungkin setelah saya rasakan itu penting juga kita harus tahu kondisi di wilayah kita bagaimana" (WH, responden dengan tingkat pendapatan di bawah UMK). Sedangkan, ISR dengan tingkat pendapatan di atas UMK menyatkan bahwa "Kadang kalo lewat beranda, kadang kalo lagi inget 'oh iyaya belum liat nih perkembangan hari ini' ya saya cari sendiri gitu di sana. Penasaran kalau ga tau kayaknya".

Ditemukan pula responden dengan pendapatan di bawah UMK dan tingkat diseminasi tinggi. Hal ini terjadi dikarenakan kekhawatirannya akan kondisi perekonomian. "Kadang-kadang saya suka muncul sendiri ga dicari juga kan. Kadang kadang saya harus cari dulu di pencarian. Karna ngaruh banget mba buat kerja, buat beraktivitas" (AL).

\section{Ikhtisar}

Struktur sosial yang menjadi salah satu faktor dari pemanfaatan media menurut McQuails (2010) pada penelitian ini dilihat dari karakteristik individu responden berupa usia, tingkat pendidikan, jenis kelamin, jenis pekerjaan, dan tingkat pendapatan. Ditemukan hubungan pada karakteristik individu usia. Ditemukan hubungan yang sangat lemah pada tingkat pendidikan dan tingkat pendapatan. Tidak ditemukan hubungan pada karakteristik jenis kelamin dan jenis pekerjaan.

\section{Hubungan Penilaian terhadap Strategi Cyber GPR dengan Tingkat Diseminasi Informasi Kesehatan Covid-19}

Selain elemen struktur sosial, struktur media juga merupakan faktor dalam pemanfaatan media oleh audiens (McQuails 2010), Pemanfaatan media ini dianalisis dengan menggunakan instrumen WebQual4.0 yang diadaptasi.

\section{Hubungan Dimensi Kegunaan dengan Tingkat Diseminasi Informasi Kesehatan Covid-19}

Analisis dimensi kegunaan menggunakan user experience terhadap bagaimana mereka menggunakan media cyber tersebut. Memahami bahwa terdapat perbedaan pada website dan media sosial, maka indikator penilaian di antara keduanya diberi perbedaan. Penelitian ini ingin melihat keterhubungan antara perepsi pengguna akan kualitas kegunaan media cyber terhadap tingkat keterdedahan informasi kesehatan Covid'19 Kabupaten Bogor. 
Tabel 22 Hasil uji korelasi antara dimensi kegunaan dengan tingkat diseminasi informasi kesehatan Covid-19

\begin{tabular}{lccc}
\hline \multirow{2}{*}{ Media } & \multicolumn{2}{c}{ Koefisien Korelasi Rank Spearman } \\
\cline { 2 - 4 } & Nilai & \multicolumn{2}{c}{ Sig* } \\
\hline Website & & 0,34 & 0,132 \\
Instagram & $-0,075$ & 0,692 \\
Twitter & $-0,286$ & 0,367 \\
Facebook & 0,527 & 0,117 \\
\hline
\end{tabular}

Ditemukan adanya hubungan yang cukup kuat pada media website. Pada Instagram, ditemukan hubungan negatif yang lemah. Pada media Twitter, ditemukan hubungan negatif yang cukup kuat dan signifikan. Pada media Facebook ditemukan hubungan positif yang kuat dan signifikan.

Tabel 23 Persentase netizen menurut tingkat dimensi kegunaan dan tingkat diseminasi website

\begin{tabular}{|c|c|c|c|c|c|}
\hline \multirow{2}{*}{$\begin{array}{l}\text { Tingkat dimensi } \\
\text { kegunaan website }\end{array}$} & \multicolumn{3}{|c|}{ Tingkat diseminasi website } & \multicolumn{2}{|c|}{ Total } \\
\hline & Rendah & Sedang & Tinggi & $\%$ & $\mathbf{n}$ \\
\hline Rendah & 0,0 & 0,0 & 0,0 & 0,0 & 0 \\
\hline Sedang & 83,3 & 16,7 & 0,0 & 100,0 & 6 \\
\hline Tinggi & 46,7 & 46,7 & 6,7 & 100,0 & 15 \\
\hline Tota & 57,1 & 38,1 & 4,8 & \multirow{2}{*}{100,0} & \multirow{2}{*}{21} \\
\hline lotal & 12 & 8 & 1 & & \\
\hline
\end{tabular}

Mayoritas responden yang memiliki tingkat penilaian terhadap dimensi kegunaan website sedang memiliki tingkat diseminasi rendah $(83.30 \%)$. Salah satu dari responden tersebut menyatakan bahwa tampilan website terlalu kaku namun informasi yang tersedia sudah memenuhi. Seperti yang dinyatakan oleh A sebagai berikut:

"Yang saya lihat terlalu kaku designnya. Tapi dari segi warna sudah cukup baik. Lebih dari tampilannya saja dikit. Disisi lain halaman depannya udah nampilin informasi yang dibutuhkan sih. Sama paling ke info grafis. Jadi bisa langsung keliatan gitu"(A)

Sedangkan, pada responden yang memiliki penilaian tinggi mayoritas memiliki tingkat diseminasi rendah dan sedang masing-masing sebesar $46.7 \%$. Hanya ada satu responden yang memiliki tingkat diseminasi tinggi dan memiliki penilaian terhadap dimensi kegunaan website tinggi. Responden ini berprofesi sebagai wartawan yang memantau keadaan Covid-19 sehari hari melalui website tersebut.

Hasil uji korelasi menggunakan Rank Spearman ditemukan nilai koefisien korelasi sebesar 0.34. dan P value sebesar $0.132>0.05$. Hasil ini membuktikan bahwa semakin tinggi penilaian terhadap dimensi kegunaan website maka semakin tinggi tingkat diseminasi informasi kesehatan Covid-19. Nilai tersebut menunjukkan hubungan yang cukup kuat namun tidak signifikan.

Tabel 24 Persentase netizen menurut tingkat dimensi kegunaan dan tingkat diseminasi Instagram

\begin{tabular}{lcrrrrr}
\hline \multirow{2}{*}{$\begin{array}{c}\text { Tingkat dimensi } \\
\text { kegunaan Instagram }\end{array}$} & \multicolumn{2}{c}{ Tingkat diseminasi Instagram } & \multicolumn{2}{c}{ Total } \\
\cline { 2 - 7 } & Rendah & Sedang & Tinggi & \% & n \\
\hline Rendah & 0,0 & 0,0 & 0,0 & 0,0 & 0 \\
Sedang & 66,7 & 33,3 & 0 & 100,0 & 3 \\
Tinggi & 63,0 & 37,0 & 0 & 100,0 & 27 \\
\hline \multirow{2}{*}{ Total } & $\%$ & 63,3 & 36,7 & 0,0 & 100,0 & 30 \\
& $\mathrm{n}$ & 19 & 11 & 0 & & 30 \\
\hline
\end{tabular}

Mayoritas responden yang memiliki penilaian terhadap dimensi kegunaan Instagram sedang memiliki tingkat diseminasi yang rendah $(66.7 \%)$. A, responden dengan penilaian tingkat dimensi kegunaan sedang dan tingkat diseminasi rendah tidak menyetujui bahwa informasi kesehatan Covid-19 memiliki tampilan yang atraktif. "Emang kurang menarik sih menurut saya. Tapi ya saya tetep aja gitu baca kalo liat timeline aja pokoknya". Hal ini juga terjadi pada responden yang memiliki tingkat penilaian tinggi 
(63.0\%). Ketika ditanyakan apakah tingkat penilaian yang tingi ini membuat NPK lebih sering dan lebih lama dalam mengakses informasi kesehatan Covid-19, NPK menyatakan bahwa:

"Aku liatnya kalo waktu itu ada tugas aja sama kalo lagi buka Instagram dan lewat timeline. Belakangan ini karna di rumah terus jadi suka buka ig (Instagram) sih tapi emang info nya suka ga lewat. Aku gamau sengaja nyari, udah bosen dan takut".

Hasil uji korelasi menggunakan Rank Spearman ditemukan nilai koefisien korelasi sebesar -0.075. dan $\mathrm{P}$ value sebesar $0.692>0.05$. Hal ini membuktikan bahwa semakin tinggi penilaian terhadap kualitas kegunaan Instagram, maka semakin menurun variabel tingkat diseminasi namun keterkaitan tersebut sangat lemah dan tidak signifikan.

Tabel 25 Persentase netizen menurut tingkat dimensi kegunaan dan tingkat diseminasi Twitter

\begin{tabular}{lcccccc}
\hline \multirow{2}{*}{$\begin{array}{c}\text { Tingkat dimensi } \\
\text { kegunaan Twitter }\end{array}$} & \multicolumn{2}{c}{ Tingkat diseminasi Twitter } & \multicolumn{2}{c}{ Total } \\
\cline { 2 - 7 } & \multicolumn{2}{c}{ Rendah } & Sedang & Tinggi & \% & n \\
\hline Rendah & 0,0 & 0,0 & 0,0 & 0,0 & 0 \\
Sedang & 0,0 & 100,0 & 0,0 & 100,0 & 3 \\
Tinggi & 44,4 & 44,4 & 11,1 & 100,0 & 9 \\
\hline \multirow{2}{*}{ Total } & $\%$ & 33,3 & 58,3 & 8,3 & 100,0 & 12 \\
& $\mathrm{n}$ & 4 & 7 & 1 & & \multirow{2}{*}{10} \\
\hline
\end{tabular}

Seluruh responden yang memiliki tingkat penilaian dimensi kegunaan sedang memiliki tingkat diseminasi yang sedang pula. Sedangkan, pada responden dengan tingkat penilaian tinggi sebagian besar memiliki tingkat diseminasi rendah dan sedang (44.4\%). YS, dengan penilaian dimensi kegunaan tinggi menyetujui bahwa informasi yang ditampilkan atraktif, membuatnya mendapat pengetahuan baru, serta penggunaan nama username yang mudah ditemukan.

"Saya sendiri kan bekerja di dunia informatika komputer gitu, jadi bisa ngebandingin mana yang lebih cocok dikonsumsi publik secara menarik gitu. Sejauh ini saya setuju udah lumayan baik. Kana kawasan kabupaten bogor ini kan memang luas. Termasuk kecamatan yang saya tinggali. Satu kecamatan ini emang ada beberapa desa. Jadi tau gitu kecamatan saya itu penyebarannya sampe beberapa. Karna gatau nih dari kecamatan saya sendiri".

Namun ketika ditanyakan apakah ini membuat YS melihat informasi kesehatan Covid-19 pada Twitter lebih sering dan lebih lama beliau menyatakan bahwa

"Stalking banget sih engga ya. Saya rasa pengguna Twitter lainnya juga begitu. Nunggu lewat aja. Kecuali ya mba, mungkin ada hal yang baru. Semisal gejala baru, pertambahan kasus tinggi baru, dan hal hal yang membuat orang tuh penasaran gitu. Kalo ini kan istilahnya udah jadi sehari-hari ya. Dimana-mana ada tentang pakai masker, $3 M$, 3T'”.

Hasil uji korelasi menggunakan Rank Spearman ditemukan nilai koefisien korelasi sebesar -0.286. dan $P$ value sebesar $0.367>0.05$. Hal ini membuktikan bahwa semakin meningkat variabel tingkat dimensi kegunaan, maka semakin menurun variabel tingkat diseminasi. Keterkaitan ini cukup kuat namun tidak signifikan.

Tabel 26 Persentase netizen menurut tingkat dimensi kegunaan dan tingkat diseminasi Facebook

\begin{tabular}{lcrrrrr}
\hline \multirow{2}{*}{$\begin{array}{c}\text { Tingkat dimensi } \\
\text { kegunaan Facebook }\end{array}$} & \multicolumn{2}{c}{ Tingkat diseminasi Facebook } & \multicolumn{2}{c}{ Total } \\
\cline { 2 - 7 } & Rendah & Sedang & Tinggi & \% & n \\
\hline Rendah & 0,0 & 0,0 & 0,0 & 0,0 & 0 \\
Sedang & 100,0 & 0,0 & 0,0 & 100,0 & 1 \\
Tinggi & 11,1 & 66,7 & 22,2 & 100,0 & 9 \\
\hline \multirow{2}{*}{ Total } & $\%$ & 20,0 & 60,0 & 20,0 & 100,0 & 10 \\
& $\mathrm{n}$ & 2 & 6 & 2 & & \\
\hline
\end{tabular}


Hanya ada satu responden yang memiliki tingkat penilaian dimensi kegunaan Facebook sedang dengan tingkat diseminasi rendah. Mayoritas responden memiliki tingkat penilaian tinggi dengan tingkat diseminasi sedang (66.7\%).

Hasil uji korelasi menggunakan Rank Spearman ditemukan nilai koefisien korelasi sebesar -0.286. dan $\mathrm{P}$ value sebesar $0.367>0.05$. Hal ini membuktikan bahwa semakin meningkat variabel tingkat dimensi kegunaan, maka semakin menurun variabel tingkat diseminasi. Keterkaitan ini cukup kuat namun tidak signifikan.

\section{Hubungan Dimensi Kualitas Informasi dengan Tingkat Diseminasi Informasi Kesehatan Covid - 19}

Analisis dimensi kegunaan menggunakan kajian sistema informasi secara umum. Pada website, penilaian ini dilihat dari kepantasan informasi bagi tujuan pengguna seperti akurasi, format, relevansi, detail, dari informasi yang disajikan. Mengingat keterbatasan karakter pada media sosial, indikator kedetailan informasi dihilangkan. Ditemukan adanya pengaruh positif antara kualitas informasi dan kualitas pelayanan terhadap tingkat kepuasan pengguna dan intensitas penggunaan layanan suatu sistem informasi (DeLone dan McLean 2003). Diduga, semakin tinggi penilaian responden terhadap kualtias informasi media cyber, semakin sering dan lama responden terdedah informasi kesehatan Covid-19. Analisis dimensi kualitas informasi terhadap tingkat diseminasi pada kasus ini dapat dilihat sebagai berikut.

Tabel 27 Hasil uji korelasi antara dimensi kualitas informasi dengan tingkat diseminasi informasi kesehatan Covid-19

\begin{tabular}{lrrr}
\hline \multirow{2}{*}{ Media } & \multicolumn{2}{c}{ Koefisien Korelasi Rank Spearman } \\
\cline { 2 - 4 } & \multicolumn{2}{c}{ Nilai } & \multicolumn{2}{c}{ Sig* } \\
\cline { 2 - 4 } Website & 0.053 & 0.82 \\
Instagram & -0.247 & 0.189 \\
Twitter & -0.398 & 0.2 \\
Facebook & 0 & 1 \\
\hline
\end{tabular}

Terdapat hubungan positif yang sangat lemah pada website dan Facebook. Sedangkan pada media Instagram ditemukan hubungan negatif yang sangat lemah. Pada Twitter ditemukan hubungan negatif yang cukup, kuat.

Tabel 28 Persentase netizen menurut tingkat kualitas informasi kegunaan dan tingkat diseminasi website

\begin{tabular}{lrrrrrr}
\hline \multirow{2}{*}{$\begin{array}{l}\text { Tingkat dimensi kualitas } \\
\text { informasi Website }\end{array}$} & \multicolumn{2}{c}{ Tingkat diseminasi website } & \multicolumn{2}{c}{ Total } \\
\cline { 2 - 7 } & Rendah & Sedang & Tinggi & \% & n \\
\hline Rendah & 0,0 & 0,0 & 0,0 & 0,0 & 0 \\
Sedang & 60,0 & 40,0 & 0,0 & 100,0 & 5 \\
Tinggi & 56,3 & 37,5 & 6,3 & 100,0 & 16 \\
\hline \multirow{2}{*}{ Total } & $\%$ & 57.1 & 38.1 & 4.8 & 100,0 & 21 \\
& $\mathrm{n}$ & 12 & 8 & 1 & \multirow{2}{*}{21} \\
\hline
\end{tabular}

Mayoritas responden yang memiliki tingkat penilaian kualitas informasi tinggi memiliki tingkat keterdedahan rendah $(56.3 \%)$. Hanya satu responden dengan penilaian tingkat kualitas informasi tinggi yang memiliki tingkat diseminasi tinggi. Responden tersebut berprofesi sebagai wartawan yang kerap memantau informasi Covid-19 sebagai bagian dari pekerjaannya.

"Karena saya sehari-hari selalu memantau perkembangan Covid-19 di Kabupaten Bogor. Kebetulan juga saya bergerak di media online. Setiap saat pemberitaan itu pun saya harus tayangin sesuai dengan keadaan Kabupaten Bogor ini". 
Ketika ditanyai mengenai kualitas informasi, bapak (IE) menyatakan bahwa informasi yang ditampilkan mudah dicerna dan dipercaya. (IE) juga percaya akan keakuratan data, update terbaru, serta detail informasi yang diberikan.

"Dilihat aja berbeda dari pada yang lain gitu mba. Dari tampilan-tampilannya. Ketika saya buka website dan mencari data pasien serta informasi covid lainnya saya melihatnya lebih mudah dan jelas. Tampilannya bagus dan rapih. Karena memang kan keterangan-keterangan yang diambil oleh Diskominfo tidak mungkin salah. Pasti lebih baik. Tidak mungkin salah dalam arti bukan memasukkan data-data pasien yang tertular, yang ODP, cukup cepat juga. Informasi kesehatan juga dikeluarkan oleh lembaga-lembaga kredibel. Memudahkan masyarakat juga dalam mencari informasi dan mengetahui keadaan di sekitarnya".

Hasil uji korelasi menggunakan Rank Spearman ditemukan nilai koefisien korelasi sebesar 0.053. Hasil ini menunjukkan bahwa semakin tinggi tingkat penilaian terhadap dimensi kualitas informasi maka semakin tinggi tingkat diseminasi informasi Covid-19. Berdasarkan nilai tersebut, hubungan antar keduanya termasuk dalam kategori sangat lemah. Nilai $P$ value sebesar $0.82>0.05$ menunjukkan hubungan yang tidak signifikan.

Tabel 29 Persentase netizen menurut tingkat kualitas informasi kegunaan dan tingkat diseminasi Instagram

\begin{tabular}{lcccccr}
\hline \multirow{2}{*}{$\begin{array}{l}\text { Tingkat dimensi kualitas } \\
\text { informasi Instagram }\end{array}$} & \multicolumn{2}{c}{ Tingkat diseminasi Instagram } & \multicolumn{3}{c}{ Total } \\
\cline { 2 - 7 } & Rendah & Sedang & Tinggi & \% & n \\
\hline Rendah & 0,0 & 0,0 & 0,0 & 0,0 & 0 \\
Sedang & 52,9 & 47,1 & 0,0 & 100,0 & 17 \\
Tinggi & 76,9 & 23,1 & 0,0 & 100,0 & 13 \\
\hline Total & $\%$ & 63,3 & 36,7 & 0,0 & 100,0 & 30 \\
& $\mathrm{n}$ & 19 & 11 & 0 & & 30 \\
\hline
\end{tabular}

Mayoritas responden memiliki tingkat diseminasi rendah. Baik responden dengan tingkat penilaian terhadap dimensi kualitas informasi sedang (52.90\%) maupun tinggi (76.90\%). AZ, responden dengan penilaian sedang dengan tingkat diseminasi rendah menyatakan bahwa: "Kurang edukatif. Itu tadi terlalu monoton data yang ditampilkan. Soalnya banyak sekali akun akun Instagram yang menampilkan tidak hanya data tapi juga ada konten edukatifnya". Sedangkan, AK, responden dengan penilaian tinggi dengan tingkat diseminasi rendah menyatakan:

"Sebenernya informasinya bagus sih, Cuma yang bikin unik itu karna ini Instagram Kabupaten Bogor, jadi infonya yang khusus kabupaten bogor aja yang aku perhatiin Kalo kaya informasi masker gitu udah sering nemu di media lain".

Hasil uji korelasi menggunakan Rank Spearman ditemukan nilai koefisien korelasi sebesar -0.247. dan $\mathrm{P}$ value sebesar $0.189>0.05$. Hal ini membuktikan bahwa semakin tinggi tingkat dimensi kegunaan, maka semakin menurun penilaian terhadap kualitas informasi Instagram. Keterkaitan ini sangat lemah dan tidak signifikan.

Tabel 30 Persentase netizen menurut tingkat kualitas informasi kegunaan dan tingkat diseminasi Twitter

\begin{tabular}{|c|c|c|c|c|c|}
\hline \multirow{2}{*}{$\begin{array}{l}\text { Tingkat dimensi kualitas } \\
\text { informasi Twitter }\end{array}$} & \multicolumn{3}{|c|}{ Tingkat diseminasi Twitter } & \multicolumn{2}{|c|}{ Total } \\
\hline & Rendah & Sedang & Tinggi & $\%$ & $\mathrm{n}$ \\
\hline Rendah & 0,0 & 100,0 & 0,0 & 100,0 & 1 \\
\hline Sedang & 20,0 & 60,0 & 20,0 & 100,0 & 5 \\
\hline Tinggi & 50,0 & 50,0 & 0,0 & 100,0 & 6 \\
\hline \multirow[t]{2}{*}{ Total } & 33,3 & 58,3 & 8,3 & \multirow{2}{*}{100,0} & \multirow{2}{*}{12} \\
\hline & 4 & 7 & 1 & & \\
\hline
\end{tabular}

Terdapat satu responden yang memiliki tingkat penilaian terhadap kualitas informasi rendah dengan tingkat diseminasi sedang. 
"Dari awal udah ga tegas ya. Jadi kepercayaan masyarakat akan media covid tuh berkurang. Ada juga informasi yang simpang siur. Jadi saya ada kayak perasaan males untuk liat informasinya. Data yang disebarkan melalui media media yang ada selalu tidak match dan lambat. Kalau dilihat lihat juga sekarang terlalu bertumpu pada pemberitaan new normal dibandingkan pemberitaan bagaimana protokol kesehatan yang baik dan sesuai. Seharusnya media dan pemerintah bisa mengakomodir semua data yang ada menjadi data yang akurat dan dapat diakses masyarakat secara real time. Dan protokol kesehatan harus selalu digalakkan lebih sering agar masyarakat sadar bahwa pandemi ini belum berakhir dan meningkatkan kewaspadaan masyarakat tanpa membuat masyarakat takut berlebihan akan covid".(MRH).

Mayoritas responden yang memiliki tingkat penilaian sedang memiliki tingkat diseminasi sedang pula (60.0\%). Sedangkan, responden yang memiliki tingkat penilaian tinggi memiliki tingkat diseminasi pada tingkat rendah dan sedang (50\%). Hasil uji korelasi menggunakan Rank Spearman ditemukan nilai koefisien korelasi sebesar -0.398. dan P value sebesar 0.2>0.05. Hal ini membuktikan bahwa semakin tinggi penilaian dimensi kualitas informasi, maka semakin rendah tingkat diseminasinya. Keterkaitan ini cukup kuat namun tidak signifikan.

Tabel 31 Persentase netizen menurut tingkat kualitas informasi kegunaan dan tingkat diseminasi Facebook

\begin{tabular}{lrrrrrr}
\hline \multirow{2}{*}{$\begin{array}{l}\text { Tingkat dimensi kualitas } \\
\text { informasi Facebook }\end{array}$} & \multicolumn{2}{c}{ Tingkat diseminasi Facebook } & \multicolumn{2}{c}{ Total } \\
\cline { 2 - 7 } & Rendah & Sedang & Tinggi & \% & n \\
\hline Rendah & 0,0 & 0,0 & 0,0 & 100,0 & 0 \\
Sedang & 33,3 & 33,3 & 33,3 & 100,0 & 3 \\
Tinggi & 14,3 & 71,4 & 14,3 & 100,0 & 7 \\
\hline Total & $\%$ & 20,0 & 60,0 & 20,0 & 100,0 & \multirow{2}{*}{10} \\
& $\mathrm{n}$ & 2 & 6 & 2 & & \\
\hline
\end{tabular}

Responden yang memiliki tingkat penilaian terhadap kualitas informasi sedang memiliki tingkat diseminasi yang beragam. Sedangkan mayoritas responden yang memiliki tingkat penilaian tinggi memiliki tingkat diseminasi sedang (71.4\%).

Ibu SS, sebagai responden dengan penilaian tinggi dan tingkat diseminasi sedang menyatakan bahwa "Kadang kalo lewat beranda, kadang kalo lagi inget 'oh iyaya belum liat nih perkembangan hari ini" ya saya cari sendiri gitu disana. Penasaran kalau gatau kayaknya" (SS).

Hasil uji korelasi menggunakan Rank Spearman ditemukan nilai koefisien korelasi sebesar 0. Dan P value sebesar 1 . Hal ini membuktikan bahwa tidak ditemukan hubungan di antara kedua variabel.

\section{Hubungan Dimensi Kualitas Interaksi dengan Tingkat Diseminasi Informasi Kesehatan Covid- 19}

Analisis tingkat interaksi dilakukan untuk melihat persepsi responden terhadap interaksi layanan yang tersedia. Poin-poin penilaian terdiri dari reputasi, rasa aman dalam bertransaksi informasi, kemudahan untuk menarik minat dan perhatian, kemudahan untuk memberi masukan (feedback), suasana komunitas, serta rasa percaya yang tinggi akan informasi yang disampaikan. Website covid19.bogorkab.id tidak memiliki fitur untuk melakukan chat secara langsung. Maka dari itu, poin penilaian rasa aman dalam bertransaksi dan kemudahan untuk memberikan masukan dihilangkan. Sedangkan, poin kemudahan untuk menarik minat dan perhatian yang dimaksud pada website adalah persepsi responden terhadap call center layanan darurat yang tersedia. Penelitian yang dilakukan oleh Mulya (2020) menemukan bahwa tingkat kualitas interaktif berhubungan secara signifikan dengan tingkat diseminasi.

"Semakin masyarakat tertarik untuk berinteraksi, merasa aman dalam berinteraksi, merasakan adanya suasana komunitas, dan menilai baik reputasi Facebook desa, maka masyarakat semakin sering dan lama dalam mengakses Facebook desa" Mulya (2020). 
Diduga, semakin tinggi penilaian responden terhadap kualitas informasi, maka semakin tinggi pula tingkat diseminasi informasi kesehatan Covid-19 responden. Analisis dimensi kualitas interaksi terhadap tingkat diseminasi pada kasus ini dapat dilihat sebagai berikut.

Tabel 32 Hasil uji koreasi antara dimensi kualitas interaksi dengan tingkat diseminasi informasi kesehatan Covid-19

\begin{tabular}{lccc}
\hline \multirow{2}{*}{ Media } & \multicolumn{2}{c}{ Koefisien Korelasi Rank Spearman } \\
\cline { 2 - 4 } & Nilai & \multicolumn{2}{c}{ Sig* } \\
\hline Website & 0.374 & 0.095 \\
Instagram & -0.327 & 0.078 \\
Twitter & -0.502 & 0.096 \\
Facebook & -0.323 & 0.363 \\
\hline
\end{tabular}

Terdapat hubungan yang cukup kuat pada website. Sedangkan pada Instagram dan Facebook ditemukan hubungan negatif yang cukup. Pada Twitter ditemukan hubungan negatif yang kuat.

Tabel 33 Persentase netizen menurut tingkat kualitas interaksi dan tingkat diseminasi website

\begin{tabular}{lcrrrrr}
\hline \multirow{2}{*}{$\begin{array}{c}\text { Tingkat dimensi } \\
\text { kualitas interaksi } \\
\text { Website }\end{array}$} & \multicolumn{2}{c}{ Tingkat diseminasi Website } & \multicolumn{2}{c}{ Total } \\
\cline { 2 - 7 } & Rendah & Sedang & Tinggi & \% & n \\
\hline Rendah & 0,0 & 0,0 & 0,0 & 0,0 & 0 \\
Sedang & 77,8 & 22,2 & 0,0 & 100,0 & 9 \\
Tinggi & 41,7 & 50,0 & 8,3 & 100,0 & 12 \\
\hline Total & $\%$ & 57,1 & 38,1 & 4,8 & \multirow{2}{*}{100,0} & 21 \\
& $\mathrm{n}$ & 12 & 8 & 1 & & 21 \\
\hline
\end{tabular}

Responden yang memiliki tingkat penilaian sedang mayoritas memiliki tingkat diseminasi rendah (77.8\%). Sedangkan responden yang memiliki penilaian tinggi mayoritas memiliki tingkat diseminasi sedang (50.0\%). Hasil uji korelasi Rank Spearman menemukan nilai korelasi sebesar 0.374 dengan $P$ value 0.095 . Hasil ini membuktikan bahwa semakin tinggi tingkat dimensi kualitas interaksi website maka semakin tinggi tingkat diseminasinya. Hubungan ini cukup kuat namun tidak signifikan. IE, responden dengan penilaian dan diseminasi tinggi menyatakan bahwa: "Kalo saya sih memang sering buka sih website itu sih. Kalo menurut saya sih cukup baik aja gitu. Tidak ada yang salah dari website itu. Website pemerintah saya rasa cenderung baik sih".

Tabel 34 Persentase netizen menurut tingkat kualitas interaksi dan tingkat diseminasi Instagram

\begin{tabular}{|c|c|c|c|c|c|}
\hline \multirow{2}{*}{$\begin{array}{c}\text { Tingkat dimensi kualitas } \\
\text { interaksi Instagram }\end{array}$} & \multicolumn{3}{|c|}{ Tingkat diseminasi Instagram } & \multicolumn{2}{|c|}{ Total } \\
\hline & Rendah & Sedang & Tinggi & $\%$ & $\mathbf{n}$ \\
\hline Rendah & 0,0 & 100,0 & 0 , & 100,0 & 1 \\
\hline Sedang & 53,5 & 46,7 & 0,0 & 100,0 & 15 \\
\hline Tinggi & 78,6 & 21,4 & 0,0 & 100,0 & 14 \\
\hline \multirow[t]{2}{*}{ Total } & 63,3 & 36,7 & 0,0 & \multirow{2}{*}{100,0} & \multirow{2}{*}{30} \\
\hline & 19 & 11 & 0 & & \\
\hline
\end{tabular}

Ditemukan bahwa mayoritas responden memiliki tingkat penilaian sedang dengan tingkat diseminasi sedang $(46.7 \%)$. IKR menyatakan bahwa:

"Kalo interaksi kan sebenarnya dari adminnya udah bilang juga ya ga bakal bales DM (direct message). Itu menurut saya sudah cukup jelas gitu. Ya menang mungkin sih masih banyak juga yang nge DM mungkin ya masyarakat kita kan kadang-kadang males komen atau ga mau ketawan komen gitu jadi ya mereka pada ngirim dm. Menurut saya sih sejauh ini adminnya cukup menjawab gitu kalo misalnya 
tanya di komen. Saya suka baca komen nya juga gitu, mereka cukup interaktif lah dalam membalas. walaupun agak lama kan beda ya kalo Instagram organisasi sama pribadi pasti ada kordinasinya dulu" (IKR).

Salah satu responden yang memiliki tingkat kualitas interaksi rendah dan tingkat diseminasi sedang memiliki pengalaman terjangkit Covid-19 dan berusaha menghubungi. Menurut AA, interaksi pada akun Instagram @ kabupatenbogor masih kurang. Di sisi lain, karena kondisinya yang sedang terjangkit Covid-19, AA memiliki tingkat diseminasi yang sedang.

"Saya perhatikan adminnya itu gapernah ngereply di komentar. Terus saya DM tentang masalah saya Covid tetap aja ga direply. Gitu lo. Jadi saya pikir ini admin cuman kaya ... kaya kreator aja gitu cuma nulis gitu tapi dia ga jadi customer service gitu loh"(AA).

Hasil uji korelasi menggunakan Rank Spearman ditemukan nilai koefisien korelasi sebesar -0.327 dan $P$ value sebesar $0.078>0.05$. Hal ini membuktikan bahwa semakin tinggi tingkat penilaian maka semakin menurut tingkat diseminasi.

Tabel 35 Persentase netizen menurut tingkat kualitas interaksi dan tingkat diseminasi Twitter

\begin{tabular}{lcrrrrr}
\hline \multirow{2}{*}{$\begin{array}{c}\text { Tingkat dimensi } \\
\text { kualitas interaksi } \\
\text { Twitter }\end{array}$} & \multicolumn{2}{c}{ Tingkat diseminasi Twitter } & \multicolumn{2}{c}{ Total } \\
\cline { 2 - 7 } & Rendah & Sedang & Tinggi & \multicolumn{1}{c}{ 年 } & n \\
\hline Rendah & 0,0 & 0,0 & 0,0 & 0,0 & 0 \\
Sedang & 14,3 & 71,4 & 14,3 & 100,0 & 7 \\
Tinggi & 60,0 & 40,0 & 0,0 & 100,0 & 5 \\
\hline Total & $\%$ & 33,3 & 58,3 & 8,3 & 100,0 & 12 \\
& $\mathrm{n}$ & 4 & 7 & 1 & & 12 \\
\hline
\end{tabular}

Mayoritas responden memiliki penilaian sedang dengan tingkat diseminasi sedang. Dapat dilihat bahwa terdapat satu responden yang memiliki penilaian sedang dengan tingkat diseminasi tingi. Menurut $\mathrm{M}$, "Akun ini tidak pasif dan akun tidak terlantar. Penyampaian informasi juga cukup baik sehingga tidak terlalu boring untuk melihat tweet yang dibuat".

Sedangkan, RI dengan penilaian sedang dan tingkat diseminasi sedang menyatakan bahwa:

"Menurut ku akun ini lebih cenderung ke formal jadi orang agak segan untuk mention dan interaksi di Twitter ini. Kalo aku boleh saran mungkin dibikin kayak ga terlalu template. Bisa dibikin kaya akunakun official lainnya yang bisa lebih komunikatif ke audiencenya".

MZY memiliki tingkat penilaian tinggi dikarenakan dirinya sering melihat bahwa ada beberapa mention yang dibalas. "Yang saya ga dibales tapi yang lain ada yang dibales". Namun, hal ini tidak membuat dirinya lebih sering dan lebih lama dalam mengakses dan mendapatkan informasi kesehatan Covid-19. "Biasanya kalo lagi dibahas di group chat atau di tongkrongan aja sih jadi lebih aware gitu pas ngomongin covidnya.

Hasil uji korelasi menggunakan Rank Spearman ditemukan nilai koefisien korelasi sebesar -0.502 dan $P$ value sebesar $0.096>0.05$. Hal ini membuktikan bahwa semakin tinggi penilaian terhadap kualitas interaksi Twitter, maka semakin menurun tingkat diseminasi. Hubungan ini kuat namun tidak signifikan. 
Tabel 36 Persentase netizen menurut tingkat kualitas interaksi dan tingkat diseminasi Facebook

\begin{tabular}{lcrrrrr}
\hline \multicolumn{2}{c}{\begin{tabular}{c} 
Tingkat penilaian \\
kualitas interaksi \\
\multicolumn{2}{c}{ Facebook }
\end{tabular}} & \multicolumn{2}{c}{ Tingkat diseminasi Facebook } & \multicolumn{2}{c}{ Total } \\
\cline { 2 - 7 } & Rendah & Sedang & Tinggi & \% & n \\
\hline Rendah & 0,0 & 0,0 & 0,0 & 0,0 & 0 \\
Sedang & 25,0 & 25,0 & 50,0 & 100,0 & 4 \\
Tinggi & 16,7 & 83,3 & 0,0 & 100,0 & 6 \\
\hline Total & $\mathrm{n}$ & 20,0 & 60,0 & 20,0 & 100,0 & 10 \\
& $\%$ & 2 & 6 & 2 & & \\
\hline
\end{tabular}

Responden yang memiliki penilaian terhadap dimensi kualitas interaksi sedang mayoritas memiliki tingkat diseminasi tinggi (50.0\%). SRS menyatakan bahwa "Kalau saya sebenarnya gak pernah berinteraksi langsung ya, hanya saja saya sering melihat adminnya suka menjawab komentar-komentar yang diberikan. Sering menanggapi. Jadi kalo menurut saya setuju sih”.

Sedangkan, responden yang memiliki tingkat penilaian tinggi memiliki tingkat diseminasi sedang (83.3\%). Bapak WH menyatakan bahwa:

"Sebenernya itu tadi, saya ga terlalu sering ya, biasa-biasa aja gitu. Tapi ya bagus lah ini bisa kita kalau mau ngasih saran kan tinggal di komen. Bisa berintraksi juga. Isinya juga kan ga boong dia mah resmi dari pemerintah".

Hasil uji korelasi menggunakan Rank Spearman ditemukan nilai koefisien korelasi sebesar -0.323 dan $P$ value sebesar $0.363>0.05$. Hal ini membuktikan bahwa semakin tinggi tingkat penilaian kualitas interaksi Facebook, maka semakin rendah tingkat diseminasi. Hubungan ini cukup kuat namun tidak signifikan.

\section{Ikhtisar}

Elemen dari media dianggap sebagai salah satu faktor pemanfaatan media oleh audiens (McQuails 2010).Elemen media pada peneltiain ini dilihat dari persepsi responden terhadap penialain kualtias media cyber. Dari keempat media cyber yang dianalisis, hanya pada website ditemukan hubungan antara penilaian terhadap strategi cyber GPR dengan tingkat keterdedahan. Hubungan yang cukup kuat ditemukan antara dimensi kegunaan dan dimensi kualitas interaksi. Sedangkan hubungan yang sangat lemah ditemukan pada dimensi kualitas informasi. Hal ini membuktikan bahwa responden akan lebih sering mengakses website jika memiliki penilaian yang baik terhadap website tersebut

Tidak ditemukan hubungan antara dimensi penilaian dengan tingkat diseminasi responden pengguna utama media sosial. Hanya saja ditemukan hubungan yang sangat lemah pada Facebook antara kualitas informasi dan tingkat keterdedahan. Temuan ini membuktikan bahwa responden akan tetap terdedah informasi kesehatan Covid-19 di media tersebut walaupun penilaian akan media tersebut dinilai belum sempurna.

\section{Hubungan Tingkat Diseminasi Informasi Kesehatan Covid-19 Terhadap Efektivitas Strategi Cyber GPR}

\section{Hubungan Tingkat Diseminasi Informasi Kesehatan Covid-19 dengan Aspek Kognitif}

Tingkat efektivitas ranah kognitif dalam penelitian ini dilihat dari persepsi responden mengenai seberapa pentingnya mengetaui informasi terkait yang terdapat dalam 7 poin protokol komunikasi publik krisis Covid-19. Semakin sering dan lama responden terdedah oleh media cyber pilihan utamanya, diduga akan semakin bertambah pengetahuan akan informasi kesehatan Covid-19. 
Tabel 37 Hasil uji korelasi antara tingkat diseminasi dengan aspek kognitif

\begin{tabular}{lccc} 
& \multirow{2}{*}{ Media } & \multicolumn{2}{c}{ Koefisien Korelasi Rank Spearman } \\
\cline { 2 - 4 } & Nilai & Sig* \\
\hline Website & 0 & 0 \\
Instagram & 0 & 0 \\
Twitter & 0 & 0 \\
Facebook & 0 & 0 \\
\hline
\end{tabular}

Berdasarkan hasil uji korelasi Rank Spearman, tidak ditemukan hubungan antara tingkat diseminasi informasi kesehatan Covid-19 dengan aspek kognitif. Hasil temuan membuktikan bahwa seluruh responden dari beragam media dengan berbagi tingkat diseminasi (rendah, sedang, tinggi) memiliki tingkat kognitif yang tinggi. Hal ini disebabkan oleh banyaknya media informasi yang mendiseminasikan mengenai informasi kesehatan Covid-19 diluat media cyber gugus tugas percepatan penanganan Covid-19 Kabupaten Bogor. "Sebenernya informasi kesehatannya itu sudah ada dimanamana ya, kalau saya naik kereta itu bahkan sudah ada di tempel tempel posternya " (BKI, pengguna media utama Instagram). Hal ini juga disetujui oleh GN sebagai pengguna media utama website "Aku biasanya ngeliat website lebih ngeliat data per bulannya aja, kalo untuk kayak info grafis kesehatan gitu-gitu masker segala macem itu udah sering berseliweran di media lain".

Selain itu, adanya pergeseran tujuan diseminasi informasi kesehatan untuk meningkatkan optimisme serta melihat aspek informasi kesehatan yang lebih luas. E, tim media center, admin Instagram @kabupatenbogor menyatakan bahwa:

"Terkait dengan covid kita sekarang sedang pemulihan bukan berbicara virus covidnya,kematiannya, tingkat sakitnya, itu sampai sekarang sedikit agak dikurangi tapi kita naikin tingkat pemulihannya. Jadi masyarakat midnsentnya sekarang tuh covid tuh meninggal berapa, sakit berapa, quota rmahsakit enuh atau tidak tapi kita mengesampingkan itiu kita lari ke pemulihan ekonomi. Kayak bupati beberapa hari yang lama misal ada acara ini pasti tetap terkait dengan coivd. Pariwisata kita upload pasti terkait covid. Pasti ada tentang covidnya. Kebudayaan, tentang covid juga. Jadi gimana masyarakat sekarang mindsetnya ayo deh gapapa ada covid tapi prokesnya jalan".

\section{Hubungan Tingkat Diseminasi Informasi Kesehatan Covid-19 dengan Aspek Afektif}

Tingkat efektivitas ranah afektif dalam penelitian ini melihat perasaan yang dimiliki responden terhadap informasi kesehatan Covid-19. Diduga semakin sering dan lama responden terdedah informasi kesehatan Covid-19 melalui media cyber Gugus Tugas Percepatan Penanganan Covid-19 Kabupaten Bogor, semakin tinggi tingkat afektifnya. Perolehan hasil penelitian dapat dilihat sebagai berikut:

Tabel 38 Hasil uji korelasi antara tingkat diseminasi dengan aspek afektif

\begin{tabular}{lcc} 
& \multirow{2}{*}{ Media } & \multicolumn{2}{c}{ Koefisien Korelasi Rank Spearman } \\
\cline { 2 - 3 } & Nilai & Sig* \\
\hline Website & 0,191 & 0,408 \\
Instagram & $-0,244$ & 0,194 \\
Twitter & 0 & 0 \\
Facebook & 0,527 & 0,117 \\
\hline
\end{tabular}

Terdapat hubungan yang sangat lemah pada website. Ditemukan pula hubungan negatif yang sangat lemah pada Instagram. Pada Facebook, ditemukan hubungan yang kuat. Sedangkan tidak ditemukan hubungan pada pengguna media utama Twitter. 
Tabel 39 Persentase netizen menurut tingkat diseminasi dan tingkat afektif website

\begin{tabular}{lcccccc}
\hline \multirow{2}{*}{$\begin{array}{c}\text { Tingkat diseminasi } \\
\text { website }\end{array}$} & \multicolumn{2}{c}{ Tingkat afektif website } & \multicolumn{2}{c}{ Total } \\
\cline { 2 - 7 } & Rendah & Sedang & Tinggi & \% & n \\
\hline Rendah & 0,0 & 8,3 & 91,7 & 100,0 & 12 \\
Sedang & 0,0 & 0,0 & 100,0 & 100,0 & 8 \\
Tinggi & 0,0 & 0,0 & 100,0 & 100,0 & 1 \\
\hline Total & $\%$ & 0,0 & 4,8 & 95,2 & \multirow{2}{*}{100,0} & \multirow{2}{*}{21} \\
& $\mathrm{n}$ & 0 & 1 & 20 & & \\
\hline
\end{tabular}

Mayoritas responden yang memiliki tingkat diseminasi rendah memiliki tingkat afektif yang tinggi (91.7\%). Sedangkan seluruh responden yang memiliki tingkat diseminasi sedang dan tinggi memiliki tingkat afektif yang tinggi. Dapat dilihat bahwa responden pengguna media utama website memiliki perasaan positif bagaimana pun tingkat keterdedahannya. Satu responden yang memiliki tingkat afektif sedang dikarenakan rasa khawatir dan takutnya terhadap Covid-19 akibat orang terdekatnya yang pernah terjangkit. "Ini kenapa orang yang sudah menjaga aja masih bisa kena"(A). Hasil uji korelasi Rank Spearman menemukan nilai korelasi sebesar 0.191 dengan $P$ value $0.408>0.05$. Hubungan ini sangat lemah dan tidak signifikan.

$\underline{\text { Tabel } 40 \text { Persentase netizen menurut tingkat diseminasi dan tingkat afektif Instagram }}$

\begin{tabular}{lcccccr}
\hline \multirow{2}{*}{$\begin{array}{c}\text { Tingkat diseminasi } \\
\text { Instagram }\end{array}$} & \multicolumn{2}{c}{ Tingkat afektif Instagram } & \multicolumn{2}{c}{ Total } \\
\cline { 2 - 7 } & Rendah & Sedang & Tinggi & \% & n \\
\hline Rendah & 0,0 & 0,0 & 100,0 & 100,0 & 19 \\
Sedang & 0,0 & 9,1 & 90,9 & 100,0 & 11 \\
Tinggi & 0,0 & 0,0 & 0,0 & 100,0 & 0 \\
\hline Total & $\%$ & 0,0 & 3,3 & 96,7 & \multirow{2}{*}{100,0} & 30 \\
& $\mathrm{n}$ & 0 & 1 & 29 & & \\
\hline
\end{tabular}

Seluruh responden yang memiliki tingkat diseminasi rendah memiliki tingkat afektif tinggi. Sedangkan, mayoritas responden yang memiliki tingkat diseminasi sedang memiliki tingkat afektif yang tinggi (90.9\%). Dapat dilihat bahwa lebih banyak responden yang memiliki tingkat afektif tinggi dengan tingkat keterdedahan yang rendah. Hasil uji korelasi Rank Spearman menemukan nilai korelasi sebesar -0.244 dengan $P$ value $0.194>0.05$. Hubungan ini sangat lemah dan tidak signifikan.

Selain karena responden Instagram terdedah informasi kesehatan Covid-19 hanya ketika informasi tersebut lewat pada timeline atau sesekali mencari karena ada kepentingan tertentu, BKI dengan tingkat keterdedahan rendah dan afektif tinggi menyatakan bahwa

"Tentunya kalau untuk informasi-informasi yang bisa mencegah saya dari terjangkitnya Covid-19 ya saya suka-suka saja liatnya, mau aja gitu merhatiin. Kan buat kesehatan juga. Kadang dari Instagram itu atau sekarang mah himbauan-himbauan teh udah banyak. Di kantor juga sering banget ada sosialisasi”.

Tabel 41 Jumlah dan Persentase netizen menurut tingkat diseminasi dan tingkat afektif Twitter

\begin{tabular}{lcccccc}
\hline \multicolumn{2}{c}{$\begin{array}{c}\text { Tingkat diseminasi } \\
\text { Twitter }\end{array}$} & \multicolumn{2}{c}{ Tingkat afektif Twitter } & \multicolumn{2}{c}{ Total } \\
\cline { 3 - 7 } & \multicolumn{2}{c}{ Rendah } & Sedang & Tinggi & \% & n \\
\hline Rendah & 0,0 & 0,0 & 100,0 & 100,0 & 4 \\
Sedang & 0,0 & 0,0 & 100,0 & 100,0 & 7 \\
Tinggi & 0,0 & 0,0 & 100,0 & 100,0 & 1 \\
\hline Total & $\%$ & 0,0 & 0,0 & 100,0 & 100,0 & 12 \\
& $\mathrm{n}$ & 0 & 0 & 12 & & \\
\hline
\end{tabular}

Hasil uji korelasi Rank Spearman membuktikan bahwa tidak ada hubungan antara tingkat diseminasi Twitter dengan tingkat afektif responden. Seluruh responden dengan berbagai tingkat diseminasi 
memiliki tingkat afektif yang tinggi. Salah satu responden menyatakan bahwa dirinya tidak merasa takut karena hal ini menyangkut kesehatanya.

"Dibilang takut sih gaboleh takut ya kak, kan tweet-tweet kaya gini ngaruhnya ke kesehatan kan, jadi mau gamau harus liat juga, harus diterapin juga. Maksudnya kalo lewat di timeline ya yauda gitu gausah di skip"(BHN, responden dengan tingkat diseminasi rendah dan afektif tinggi).

Tabel 42 Persentase netizen menurut tingkat diseminasi dan tingkat afektif Facebook

\begin{tabular}{|c|c|c|c|c|c|c|}
\hline \multirow{2}{*}{\multicolumn{2}{|c|}{$\begin{array}{c}\text { Tingkat diseminasi } \\
\text { Facebook }\end{array}$}} & \multicolumn{3}{|c|}{ Tingkat afektif Facebook } & \multicolumn{2}{|c|}{ Total } \\
\hline & & Rendah & Sedang & Tinggi & $\%$ & $\mathbf{n}$ \\
\hline \multicolumn{2}{|c|}{ Rendah } & 0,0 & 50,0 & 50,0 & 100,0 & 2 \\
\hline \multicolumn{2}{|c|}{ Sedang } & 0,0 & 0,0 & 100,0 & 100,0 & 6 \\
\hline \multicolumn{2}{|l|}{ Tinggi } & 0,0 & 0,0 & 100,0 & 100,0 & 2 \\
\hline \multirow[t]{2}{*}{ Total } & $\%$ & 0,0 & 10,0 & 90,0 & \multirow{2}{*}{100,0} & \multirow{2}{*}{10} \\
\hline & $\mathrm{n}$ & 0 & 1 & 9 & & \\
\hline
\end{tabular}

Responden yang memiliki tingkat diseminasi rendah memiliki tingkat afektif yang sedang dan tinggi masing-masing sebesar $50.0 \%$. Seluruh responden dengan tingkat diseminasi sedang dan tinggi memiliki tingkat afektif yang tinggi. ISR, satu-satunya responden dengan tingkat diseminasi rendah dan afektif sedang menyatakan bahwa "Ya was-was neng,takut banget saya tu bawaan ibu-ibu kali ya teh. Kalo kena gimana gitu anak suami. Jadi mau patuhi mah patuhi atuh tapi teh seperlunya aja lah bukanya".

Hasil uji korelasi Rank Spearman menemukan nilai koefisien korelasi sebesar 0.527 dan nilai $P$ value sebesar $0.117>0.05$. Hasil ini membuktikan bahwa semakin tinggi tingkat diseminasi Facebook maka semakin tinggi tingkat afektif responden. Hubungan antar kedua variabel kuat namun tidak signifikan.

\section{Hubungan Tingkat Diseminasi Informasi Kesehatan Covid-19 dengan Aspek Konatif}

Tingkat konatif dilihat dari kecenderungan berperilaku responden terhadap pandemi Covid-19 setelah mendapatkan informasi kesehatan Covid-19 sesuai protokol komunikasi publik mengenai pencegahan, deteksi dini mandiri, karantina, rumah sakit rujukan Covid-19. Diduga tingkat diseminasi yang tinggi berhubungan dengan tingkat konatif responden yang tinggi. Hasil penelitian dipaparkan sebagai berikut.

\section{Tabel 43 Hasil uji korelasi antara tingkat diseminasi dengan aspek konatif}

\begin{tabular}{|c|c|c|}
\hline \multirow{2}{*}{ Media } & \multicolumn{2}{|c|}{ Koefisien Korelasi Rank Spearman } \\
\hline & Nilai & Sig* \\
\hline Website & 0,191 & 0,408 \\
\hline Instagram & $-0,074$ & 0,698 \\
\hline Twitter & 0 & 0 \\
\hline Facebook & 0 & 0 \\
\hline
\end{tabular}

Terdapat hubungan positif yang sangat lemah pada website dan hubungan negatif yang sangat lemah pada Instagram. Hasil uji korelasi ini menemukan bahwa tidak ada hubungan antara tingkat diseminasi pada media Twitter dan Facebook dengan tingkat konatif responden pengguna media utama tersebut. 
Tabel 44 Persentase netizen menurut tingkat diseminasi dan tingkat konatif website

\begin{tabular}{lcccccc}
\hline \multirow{2}{*}{$\begin{array}{c}\text { Tingkat diseminasi } \\
\text { website }\end{array}$} & \multicolumn{2}{c}{ Tingkat konatif website } & \multicolumn{2}{c}{ Total } \\
\cline { 2 - 7 } & Rendah & Sedang & Tinggi & \% & n \\
\hline Rendah & 0,0 & 8,3 & 91,7 & 100,0 & 12 \\
Sedang & 0,0 & 0,0 & 100,0 & 100,0 & 8 \\
Tinggi & 0,0 & 0,0 & 100,0 & 100,0 & 1 \\
\hline Total & $\%$ & 0,0 & 4,8 & 95,2 & \multirow{2}{*}{100,0} & \multirow{2}{*}{21} \\
& $\mathrm{n}$ & 0 & 1 & 20 & & \\
\hline
\end{tabular}

Mayoritas responden yang memiliki tingkat diseminasi rendah memiliki tingkat konatif yang tinggi (91.7\%). Seluruh responden dengan tingkat diseminasi sedang dan tinggi memiliki tingkat konatif yang tingi. Hal ini membuktikan bahwa seberapa pun tingkat diseminasi, responden tetap memiliki tingkat konatif yang tinggi. GN, responden dengan tingkat diseminasi rendah dan konatif tinggi menyatakan bahwa:

“Cuma sekali-sekali aja biar tau informasinya. Iseng aja gitu ngeliat rumah sakit rujukan, fasilitas pelayanan gitu begitu. Karna aku biasanya ngeliat website lebih ngeliat data per-bulannya aja, kalo untuk kayak infografis kesehatan gitu-gitu masker segala macem itu udah sering berseliweran di media lain. Yang aku rasa juga lebih bikin aku kayak tergerak memang ga cuma dari website ini aja sih. Benerbener dimana-mana dan sering gitu dikeseharian kedenger atau keliat”.

Hasil uji korelasi Rank Spearman menemukan nilai koefisien korelasi sebesar 0.191 dan Nilai $P$ value sebesar $0.408>0.05$. Hasil ini membuktikan bahwa semakin tinggi tingkat diseminasi website maka semakin tinggi tingkat konatif responden.

Tabel 45 Persentase netizen menurut tingkat diseminasi dan tingkat konatif Instagram

\begin{tabular}{lcccrcc}
\hline \multirow{2}{*}{$\begin{array}{c}\text { Tingkat diseminasi } \\
\text { Instagram }\end{array}$} & \multicolumn{2}{c}{ Tingkat konatif Instagram } & \multicolumn{2}{c}{ Total } \\
\cline { 2 - 7 } & Rendah & Sedang & Tinggi & \% & n \\
\hline Rendah & 0,0 & 5,3 & 94,7 & 100,0 & 19 \\
Sedang & 0,0 & 9,1 & 90,9 & 100,0 & 11 \\
Tinggi & 0,0 & 0,0 & 0,0 & 0,0 & 0 \\
\hline Total & $\%$ & 0,0 & 6,7 & 93,3 & \multirow{2}{*}{100,0} & \multirow{2}{*}{30} \\
& $\mathrm{n}$ & 0 & 2 & 28 & & \\
\hline
\end{tabular}

Mayoritas responden yang memiliki tingkat diseminasi rendah dan sedang memiliki tingkat konatif yang tinggi masing-masing sebesar $94,7 \%$ dan $90.9 \%$. $\mathrm{MKH}$, responden dengan tingkat diseminasi rendah dan konatif tinggi menyatakan bahwa informasi di Instagram bukan faktor utama yang mempengaruhi aspek konatifnya terhadap informasi kesehatan Covid-19.

"Sebenarnya pengaruh ga pengaruh ya ka. Kalau kita melihat Instagram nya juga, mereka nyebarin informasi tentang info-info protokol kesehatan dan lain lain kaya gitu, kita juga naatin gitu loh. Tapi, dari sisi lain juga ada kegiatan-kegiatan yang mengharuskan kita keluar rumah. Walaupun kita harus keluar rumah, tapi kita juga harus tetap apa ya, menaati protokol gitu gituloh. Jadiapa ya, pengaruh ga pengaruh".

Hasil uji korelasi Rank Spearman menemukan nilai koefisien korelasi sebesar -0.074 dan Nilai $P$ value sebesar $0.698>0.05$. Hal ini membuktikan bahwa semakin meningkat variabel tingkat diseminasi Instagram maka semakin menurun variabel tingkat afektif responden. Hubungan ini sangat lemah dan tidak signifikan

\section{Ikhtisar}

Tingkat diseminasi responden tidak berhubungan dengan aspek kognitif informasi Covid-19. Seluruh responden memiliki tingkat kognitif yang tinggi. Hal ini membuktikan persepsi masyarkat mengenai pentingnya mengetahui informasi kesehatan Covid-19 sudah baik. Begitu pula dengan aspek afektif. Ditemukan hubungan yang sangat lemah pada website dan hubungan yang kuat pada Facebook. Namun 
pada Facebook ditemukan hanya 1 responden yang memiliki tingkat diseminasi rendah dengan tingkat afektif sedang. 9 Responden lainnya memiliki tingkat diseminasi yang beragam dengan mayoritas tingkat afektif tinggi. Hubungan yang sangat lemah ditemukan pula pada tingkat diseminasi responden pengguna media cyber website dengan aspek konatif

\section{KESIMPULAN}

Ditemukan hubungan yang cukup kuat antara usia dengan tingkat diseminasi website. Semakin tua usia maka semakin sering mengakses website. Website juga merupakan satu-satunya media cyber yang diakses oleh responden dari beragam kategori usia. Pada Instagram dan Twitter, mayoritas berasal dari ketogori usia masa remaja akhir. Sedangkan Facebook di dominasi oleh masa dewasa awal. Elemen struktur sosial lainnnya hanya ditemukan hubungan yang lemah dan tidak signifikan. Seluruh responden dari masing-masing media mayoritas berjenis kelamin laki-laki. Dilihat dari jenis pekerjaan, mayoritas netizen website dan Twitter berstatus mahasiswa. Pada Instagram mayoritas karyawan swasta, dan pada Facebook ditemukan netizen yang berasal dari beragam jenis pekerjaan yang masuk dalam kategori lainnya. Seluruh responden mayoritas memiliki pendapatan dibawah UMK. Dilihat dari tingkat pendidikan, mayoritas responden website dan Twitter memiliki tingkat pendidikan akhir SMA/sederajat. Ditemukan hubungan yang sangat lemah pada tingkat pendidikan (pada seluruh media cyber) dan pendapatan (hanya pada Twitter) dengan tingkat diseminasi.

Keterdedahan informasi dari media cyber website berhubungan dengan penilaian pengakses terhadap website tersebut. Penilaian dari berbagai dimiensi sudah tinggi. Akan tetapi masih ditemukan kekurangan pada dimensi kualitas informasi yakni penggunaan bahasa yang tidak umum. Pada media sosial, responden akan tetap terdedah informasi kesehatan Covid-19 walaupun media sosial tersebut dinilai belum sempurna. Ketidaksempurnaan ini disebabkan masih ditemukannya ketidak rapihan tata letak konten pada feeds Instagram, belum dimanfaatkannya beberapa fitur interaksi seperti live dan fitur bertanya pada Instagram story, jadwal posting yang belum konsisten pada seluruh media sosial, gaya bahasa penulisan caption, serta masih kurangnya pembalasan komentar oleh admin media sosial.

Perubahan sikap sebagai tolak ukur efektivitas diseminasi informasi kesehatan Covid-19 tidak berhubungan dengan tingkat keterdedahan responden. Mayoritas responden sudah memiliki tingkat kognitif, afektif, dan konatif yang baik dengan beragam tingkat keterdedahan

\section{SARAN}

1. Kalangan akademisi, penelitian ini diharapkan dapat menjadi bahan diskusi dalam mengembankan ilmu strategi cyber GPR dalam diseminasi informasi kesehatan sebagai bentuk komunikasi krisis.

2. Praktisi GPR, menggunakan website sebagai pusat informasi krisis karena ditemukan bahwa website menjadi media yang mudah diakses oleh penduduk dari berbagai kategori usia. Penggunaan website perlu memperhatikan penggunaan bahasa yang mudah dimengerti serta mempertimbangkan kualitas kegunaan, informasi, dan interaksi karena tingkat diseminasi akan semakin tinggi ketika netizen memiliki penilaian yang baik akan website tersebut. Perlu mempertimbangkan pula penggunaan media sosial secara interaktif dengan waktu upload yang konsisten. Peningkatan interaksi pada media sosial dapat dilakukan dengan memaksimalkan fitur-fitur interaksi yang tersedia dan membalas komentar netizen yang relevan. Konsistensi waktu upload konten dapat dilakukan dengan mencegah hambatan eksternal seperti data yang belum masuk dari divisi tertentu. Hal ini dapat diatasi dengan membuat beberapa draft konten cadangan yang mengandung informasi terkait krisis sehingga masyarakat masih tetap terdedah dengan informasi dan tidak memiliki persepsi kurangnya informasi pencegahan krisis terkait. Penggunaan gaya bahasa caption di media sosial juga dapat disesuaikan menjadi tidak terlalu kaku agar netizen lebih merasa nyaman untuk berinteraksi.

3. Pemerintah, ditemukan bahwa kurangnya tingkat interaksi pada media sosial disebabkan oleh adanya pembagian tanggung jawab untuk mengklarifikasi informasi yang diminta atau ditanyakan oleh masyarakat. Mengingat penyampaian informasi di media sosial dapat terkait dengan bidang kepemerintahan lainnya, hambatan birokrasi dapat ditangani melalui komunikasi pada online group yang efektif. Khususnya program diseminasi informasi ketika menghadapi kondisi krisis. 



\section{DAFTAR PUSTAKA}

Andika J. 2008. Hubungan keterdedahan terhadap media massa dengan pengetahuan tentang kebijakan pemerintah mengenai flu burung (Kasus pada mahasiswa fakultas peternakan institut pertanian bogor).[skripsi][diakses 2020 Sep 1] Bogor (ID): Institut Pertanian Bogor. https://repository.ipb.ac.id/jspui/bitstream/123456789/10508/1/D08jan.pdf

Adhanisa C, Fatchiya A. 2017. Efektivitas website dan Instagram sebagai sarana promosi kawasan wisata berbasis masyarakat. [diakses pada 2020 Feb 2] JSKPM.1(4), 451-466. https://doi.org/10.29244/jskpm.1.4.451-466

Argenti PA. 2009. Corporate Communication. New York (US): McGraw Hill. hlm 256. edisi ke-5.

[APJII] Asosiasi Penyelenggara Jasa Internet Indonesia. 2018. Laporan Survei Penetrasi \& Profil

Perilaku Pengguna Internet Indonesia. [diakses pada 2020 Jul 17] https://apjii.or.id/survei2018s/download/Atg2u8Lex9bqDTNdzPGCBhaXn1m6vO

Artis. 2011. Strategi komunikasi public relations. Jurnal Sosial Budaya. [diakses pada 2020 Sep 1] (8):2 hlm 184-197. https://media.neliti.com/media/publications/40435-ID-strategikomunikasi-public-relations.pdf

Azwar S. 2011. Sikap Manusia: Teori dan Pengukurannya. Ed. 2. Yogyakarta: Pustaka Pelajar. Ayobogor. 2020 Jul 17. Mulai 17 Juli, warga kabupaten bogor tidak pakai masker didenda Rp50 ribu. AyoBogor.com. [diakses pada 2020 Agu 19]. https://www.ayobogor.com/read/2020/07/17/7797/mulai-17-Juli-warga-kabupatenbogor-tidak-pakai-masker-didenda-rp50-ribu

Babbie E. 2014. The Practice of Social Research. 14 ${ }^{\text {th }}$ edition. Canada (CA): Cengange Barning.

[Bappeda Jawa Barat] Badan Perencanaan Pembangunan Daerah Provinsi Jawa Barat. 2019 des 01. Gubernur Ridwan Kamin Tetapkan Kepgub UMK 2020. [diakses pada 202019 Sep]. http://bappeda.jabarprov.go.id/gubernur-ridwan-kamil-tetapkan-kepgub-umk-2020/

Barnes SJ. Vidgen R. Measuring Web site quality improvements: a case study of the forum on strategic management knowledge exchange. Industrial Management \& Data Systems [diakses pada 2020 Jul 29] 103(5): 297-309. http://citeseerx.ist.psu.edu/viewdoc/download;jsessionid=28093C70A8B916344F983A5 1E7E32F85?doi=10.1.1.101.1705\&rep=rep1\&type $=$ pdf

Budi R. 2010. Pengantar Ilmu Komunikasi. Kretakupa print: Makassar (ID). hlm 6. [diakses pada 2020 Agu https://www.academia.edu/36452157/BUKU_PENGANTAR_ILKOM_WM_pdf

Budiaji W. 2013. Skala pengukuran dan jumlah respons skala likert. Jurnal lmu Pertanian dan Perikanan. [diakses pada 2020 Agu 02].2(2): 127- 133. ISSN 2302-6308. http://www.umbidharma.org/jipp/index.php/jipp/a rticle/view/36/29

Bupati Kabupaten Bogor. 2020. Keputusan No 360/216/Kpts/Per-UU/2020 tentang Perubahan Kedua atas Keputusan Bupati Bogor Nomor 360/200/Kpts/Per-UU/200 Tentang Pembentukan Gugus Tugsa Percepatan Penanganan Coronavirus Disease 2019 (Covid-19) di Kabupaten Bogor. [diakses pada 2020 Agu 19]. Tersedia pada https://ppid.bogorkab.go.id/index.php?d=10168\&page_title=SK_Bupati_bogor_no_36 0/216/Kpts/Per_UU/2020

Burhan. 2018. Pemanfaatan teknologi informasi dan komunikasi untuk pengembagnan ekonomi petanian dan pengentasan kemiskinan. JKP. [diakses pada 2020 Sep 8]. 16 (2) hlm 234. Tersedia pada https://journal.ipb.ac.id/index.php/jurnalkmp/article/view/26338/17048

[BPS] Badan Pusat Statistik Kabupaten Bogor. 2020 Sep 9. Konsep. [diakses pada 2020 Sep 9]. https://bogorkab.bps.go.id/subject/12/kependudukan.html\#subjekViewTab1

[BPS] Badan Pusat Statistik Kabupaten Bogor. 2020 Sep 9. Konsep. [diakses pada 2020 Sep 9]. https://bogorkab.bps.go.id/subject/12/kependudukan.html\#subjekViewTab1

[BPS] Badan Pusat Statistik Kabupaten Bogor. 2020. Kabupaten Bogor dalam Angka 2020. Bogor (ID). Hlm 54.

[BPS] Badan Pusat Statistik .2021. The indonesian population cencus Uinted Nation Expert Group Meeting 2020. (2021 [feb] 9-12). Pertemuan dating.. 
https://unstats.un.org/unsd/demographic-social/meetings/2021/egm-covid19-census20210209/docs/s03-04-IDN.pdf

Colton D, Covert RW. 2007. Designing and Contructing Instruments for Social Research and Evaluation. Jossey-Bass: San Francisco (CA).pg 9

Combs TW. 2012. Ongoing Crisis Communication: Planning, Managing and Responsding. Los Angeles (USA): SAGE hlm 2. Edisi ke-3. [diakses pada 2020 Agu 11]. https://books.google.co.id/books?id=r6K0pRwbNn0C \&printsec=frontcover\&hl=id\&sou $\mathrm{rce}=\mathrm{gbs} \_\mathrm{ge} \_$summary_r$\& \mathrm{cad}=0 \# \mathrm{v}=$ onepage $\& \mathrm{q} \& \mathrm{f}=$ false

Cutlip SM, Center AH, Broom GM. 2006. Effective Public Relation. Wibowo T, penerjemah. Jakarta (ID): Kencana. Ed. ke-9

Crespi I. 1997. The Public Opinion Process: How the People SpeakNew York (US): Routledge.pg 17-20. [diakses pada 2020 Sep 13] https://books.google.co.id/books?id=tS_8AQAAQBAJ\&printsec=copyright\&red ir_esc $=\mathrm{y} \# \mathrm{v}=$ onepage $\& \mathrm{q} \& \mathrm{f}=$ false

Creswell JW. 2007. Qualitative Inquiry \& Research Design: Choosing among Five Approaches (second Edition) California (US): SAGE Publications. [diakses pada 2020 Sep 20]. Inchttps://www.academia.edu/33813052/Second_Edition_QUALITATIVE_INQUIRY_ and_RESEARCH_DESIGN_Choosing_Among_Five_Approaches

Daryanto. 2014. Teori Komunikasi. Gunung Samudera: Malang (ID) hlm 6. [diakses pada 2020 Agu $01]$

https://books.google.co.id/books?id=W0MyDwAAQBAJ\&printsec=frontcover\&hl=id\# $\mathrm{v}=$ onepage $\& \mathrm{q} \& \mathrm{f}=$ false

[DINKES KAB BOGOR]. Dinas Kesehatan Kabupaten Bogor. Apa itu kesehatan. [diakses pada 2020 Agu 02]. http://dinkes.bogorkab.go.id/links/apa-itu-kesehatan-2/

[DISKOMINFO KAB BOGOR] Dinas Komunikasi dan Informatika Kabupaten Bogor. 2020 Apr 14. Divis komunikasi publik gugus tugas Covid-19 sinergis sosialisasikan penanganan virus corona kepada masyarakat. [diakses pada 2020 Jul 29]. bogorkab.go.id. https://bogorkab.go.id/post/detail/divis-komunikasi-publik-gugus-tugas-Covid-19sinergis-sosialisasikan-penanganan-virus-corona-kepada-masyarakat

[DISKOMINFO KAB BOGOR] Dinas Komunikasi dan Informatika Kabupaten Bogor. 202019 Agu. Bogor untuk siap siaga corona. Covid-19.bogorkab.go.id. https://Covid19.bogorkab.go.id/

[DISKOMINFO KAB BOGOR] Dinas Komunikasi dan Informatika Kabupaten Bogor. 2020. Profil diskominfo. [diakses pada 2020 Sep 1]. diskominfo.bogorkab.go.id. https://diskominfo.bogorkab.go.id/1705-2/

[DISKOMINFO KAB BOGOR] Dinas Komunikasi dan Informatika Kabupaten Bogor. 2020. [diakses pada $2020 \quad$ Sep 1]. Tupoksi. diskominfo.bogorkab.go.id. https://diskominfo.bogorkab.go.id/tupoksi-2/

De Fleur ML. 1989. Theories of mass communication. Boston (US): Houghton Mifflin Co.

DeLone WH, McLean ER. 2003. The deLone and mcLean model of information systems success: a tenyear update management information system. Journal of Management Informations. [diakses pada: 2020 Sep 1]19(4): 9-30. http://www.asiaa. sinica.edu.tw/ ccchiang/GILIS /LIS/p9-Delone.pdf

Dewi AS. 2011. Radio komunitas dan disaster risk reduction: studi kasus radio lintas merapi di klaten jawa tengah dan radio angkringan di yogyakarta. Jurnal Sosiologi DeliMa. [diakses pada 2020 Sep 1]; 27(2): 181-188. https://core.ac.uk/download/pdf/20333438.pdf\#page=97

Gugus Tugas Percepatan Penangan Covid-19 2020. Protokol percepatan penanganan pandemi COVID19 (corona virus disease 2019).[diakses pada 2020 Agu 09]. https://covid19.go.id/storage/app/media/Protokol/Protokol\%20Percepatan\%20Penangan an\%20Pandemi\%20Corona\%20Virus\%20Disease\%202019.pdf

Griffin EA. 2012. A First Look at Communication Theory. McGraw-Hill: New York (USA). Pg 6. [diakses pada $2020 \quad$ Agu https://www.academia.edu/9437521/Communication_Theory 
Grunig JE, HuntT. 1984. Managing public relations. New York: Holt, Rinehart, \& Winston.

Hartono D. 2016. Psikologi: Modul Bahan Ajar Cetak Keperawatan. Jakarta (ID): Kementrian Kesehatan Republik Indonesia. [diakses pada 2020 Agu 28]. http://bppsdmk.kemkes.go.id/pusdiksdmk/wp- content/uploads/2017/08/PsikologiKepera watan-Komprehensif.pdf

Hayati R. 2019 Jun 16. Pengertian teknik samping, jenis, dan contohnya. [diakses pada: 2020 Sep 19]. https://penelitianilmiah.com/tekniksampling/\#: :text=Sampling\%20Sukarela\%20(Voluntary\%20Sampling),banyak\%20dig unakan\%20dalam\%20jajak\%20pendapat.

Hidayat D. 2013. Be A Good Communicator: Terapi Komunikasi Efektif Dilengkapi Teknik Praktis Mengolah Vokal. Jakarta (ID): Alex Media Komputindo.

Jefkins F. 1992. Public Relations. Jakarta (ID): Intermasa.

Jo S, Kim Y. 2009. The effect of web characteristics on reward building. Journal of Public Relations Research. [diakses pada 2020 Feb 1]. 15(3), 199-223. https://doi.org/10.1207/S1532754XJPRR1503_1

Khatimah H. 2020 Apr 09. Kabupaten bogor alokasikan Rp384 miliar untuk penanganan Covid-19. Fatubun A, editor. AyoBogor.com. [Diakses pada 2020 Agu 19]. https://www.ayobogor.com/read/2020/04/09/6608/kabupaten-bogor-alokasikan-rp384miliar-untuk-penanganan-Covid-19

Kriyantono. 2018. Public Relations, Issue \& Crisis Management: Pendekatan Critical Public Relations, Etnografi Kritis \& Kualitatif. Jakarta (ID): Kencana PrenadaMedia Group.hlm 173.https://books.google.co.id/books/about/Public_Relations_Issue_Crisis_Management .html?id=hey2DwAAQBAJ\&printsec=frontcover\&source=kp_read_button\&redir_esc $=$ $\mathrm{y} \# \mathrm{v}=$ onepage $\& \mathrm{q}=\mathrm{krisis} \& \mathrm{f}=$ false

[KSP] Kantor Staf Presiden. 2020. Penanganan Covid-19: protokol komunikasi publik. [intertet] [diakses pada 2020 Agu 15]. https://ksp.go.id/wp-content/uploads/2020/03/ProtokolKomunikasi-COVID-19.pdf

Kusumajanti, Purnama M, Priliantinic A.2018. Diseminasi informasi publik oleh humas kementerian kelautan dan perikanan republik indonesia dalam meningkatkan public awareness: studi kasus terkait larangan penggunaan pukat hela dan pukat trawl pada nelayan di kepulauan seribu. Jurnal komunika [diakses pada Feb 03] (7):3. http://dx.doi.org/10.31504/komunika.v7i3.1630

Liliweri A. 2008. Dasar-dasar Komunikasi Kesehatan. Jakarta (ID): Pustaka Pelajar.

McQuail D. 2010. Mc Qual's Mass Communication Theory. [diakses pada 2020 Agu 02]. Padstow (UK): SAGE: $\quad$ hlm: $116,296 . \quad$ Edisi $\quad$ ke- 6 https://www.academia.edu/36441695/McQuails_Mass_Communication_Theory

Mulya CD. 2020. Efektivitas Facebook desa sebagai media penyebaran informasi pembangunan desa: Kasus Facebook desa curug 'curug berhati', kecamatan gunungsinder, kabupaten bogor. [skripsi] [diakses pada 2020 Agu 02] Bogor (ID): Institut Pertanian Bogor. http://repository.ipb.ac.id/handle/123456789/102447

Mulyadi M. 2011. Penelitian kuantitatif dan kualitatif serta pemikiran dasar menggabungkannya. Jurnal studi komunikasi dan media. [diakses pada 2020 Sep 19]. (15)1: 127-138. https://media.neliti.com/media/publications/134513-ID-penelitian-kuantitatif-dankualitatif-se.pdf

Mulyawaty S. 2016. Efektivitas website desa sebagai media penyebaran informasi pembangunan desa malasari kabupaten bogor. [tesis][diakses pada 2020 Sep 1]. Bogor (ID): Institut Pertanian Bogor http://repository.ipb.ac.id/handle/123456789/82863

Murairwa S. 2015. Voluntary sampling. International Journal of Advanced Research in Management and Social Sciences. [diakses pada 2020 Sep 19]. (4) 2: 185-200. https://www.researchgate.net/publication/340000298_VOLUNTARY_SAMPLING_DE SIGN

Nova F. 2017. Crisis Public Relations: Strategi PR Menghadapi Krisis, Mengelola Isu, Membangun Citra dan Reputasi Perusahaan. Depok (ID): RajaGrafindo Persada. 
Notoatmodjo, S. (2007). Promosi kesehatan dan ilmu perilaku. Rineka Cipta: Jakarta (ID).

Nurdin I, Hartati S. 2019. Metodologi Penelitian Sosial. [diakses pada 202019 Sep] Surabaya (ID):

Media Sahabat Cendekia.

http://eprints.ipdn.ac.id/4510/2/BUKU\%20METODOLOGI\%20PENELITIAN\%20SOS

IAL.pdf

Onggo BJ.2004. Cyber Public Relations. Jakarta: PT. Media Elex Komputindo (Gramedia Group).

[OECD]. 2018. Brigding The Digital Gender Divide: Include, Upskill, Innovate. . [diakses pada 8 agu 2021]. https://www.oecd.org/digital/bridging-the-digital-gender-divide.pdf

Presiden Republik Indonesia. 1989. Undang-Undang Republik Indonesia Nomor 2 Tahun 1989 tentang Sistem Pendidikan Nasional. [diakses pada: 2020 Sep 19]/ http://www.dpr.go.id/dokjdih/document/uu/591.pdf

[PERMENDAGRI]. Peraturan Menteri Dalam Negeri Nomor 13 Tahun 2011 Tentang Pedoman Pelaksanaan Tugas Kehumasan di Lingkungan Kementerian Dalam Negeri dan Pemerintah Daerah. [diakses pada 2020 Jul 01] http://ditjenpp.kemenkumham.go.id/arsip/bn/2011/bn131-2011.htm

Pemerintah Republik Indonesia. 2002. Undang-Undang Republik Indonesia Nomor 24 Tahun 2007 tentang Penangulangan Bencana. [Diakses pada 2020 Agu 19]. https://bnpb.go.id/ppid/file/UU_24_2007.pdf

Rusdiana A.2014. KonSep Inovasi Pendidikan. Pustaka Setia. Bandung (ID). Hlm 65. [diakses pada 2020 Agu http://digilib.uinsgd.ac.id/8787/1/Buku\%20KonSep\%20Inovasi\%20Pendidikan.pdf

Ruslan R. 2012. Manajemen Public Relations dan Media Komunikasi. Jakarta (ID): Rajagrafindo Persada.

Robbins SP, Judge TA. 2012. Organizational Behaviour. Edisi ke-15. New Jersey (US): Pearson Education. [diakses pada 2020 Agu https://www.researchgate.net/profile/Narendra_Chaudhary9/post/Influence_of_leadershi p_on_trust_organizational_performance/attachment/59d62af079197b8077989550/AS\% 3A341225224851456\%401458365841566/download/organizational-behavior-15estephen-p-robbins-timothy-a-judge-pdf-qwerty.pdf

Rodman G. 2006. Mass Media in Changing World. First Edition. USA (US): Mc Graw and Hill Inc.

Sari BWN.2009. Government Public Relations. Jakarta (ID): Graha Ilmu.

Sastropoetro SRA. 1990. Pendapat Khalayak dalam Komunikasi Sosial. Bandung (ID): Remaja Rosdakarya

Singarimbun M. Effendi S. 2012. Metode Penelitian Survei.Jakarta (IDE): LP3ES

Schramm W. 1973.Men, Messages, and Media: A Look at Human Communication Management. Gruning EJ, editor. New York (US): Harper and Row. Pg 51

Sellnow TL, Seeger MW. 2013. Theorizing Crisis Communication.West Sussex (UK): Wiley-Blackwell: hlm 2

Setyaningrum E. 2017. Keterdedahan internet dan perilaku aktif penduduk dalam pengelolaan anggaran pendapatan dan belanja desa. [skripsi][diakses pada 2020 Agustus 19]. http://repository.ipb.ac.id/handle/123456789/87268

Susilowati D, Paryanta. 2015. Website desa jetis untuk membantu mengelola data penduduk dan dana desa. Jurnal Ilmiah Go Infotech. [diakses pada 2020 Feb 3] 21(2), 693-697. https://ijmmu.com/index.php/ijmmu/article/view/879/640

Sutrisno E, Astuti IDN, Rahmanto AN. 2019. The communication of cyber public relations (CPR) bureaucracy in the field of social media. JJMU. [diakses pada 2020 Feb 3]. 6(3), 693697. https://ijmmu.com/index.php/ijmmu/article/view/879/640

Tede M. 2012. Pengaruh program siaran radio pertanian ciawi bagi pendengarnya: kasus pendengar di desa cileungsi, kecamatan ciawi, kabupaten bogor). [skripsi] [diakses pada 2020 Sep 1] Bogor (ID): Institut Pertanian https://repository.ipb.ac.id/handle/123456789/54424 
Ulfa N, Suadnya W, Khusnia HN. 2019. Manajemen krisis humas pemerintah daerah kabupaten lombok utara. Jurnal Of Media and Communication Science. [diakses pada 2020 apr 29].2(2), 97115.https://doi.org/10.29303/jcommsci.v2i2.48

Wahyudin U, Sugiana D. 2018. Penggunaan Media Digital untuk Penanganan KLB Difteri. Jurnal Common. [diakses pada 2020 apr 29]. 2(1), 13-21. https://doi.org/10.34010/common.v2i1.870

Wardah M. 2017. Pengelolaan website sebagai media informasi publik pada bagian humas dan informasi pemerintah kota pekanbaru. [diakses pada 2020 Feb 3]. JOM FISIP. 14(1) https://jom.unri.ac.id/index.php/JOMFSIP/article/view/13033/12675

Wasesa SA. 2006. Strategi Public Relations [diakses pada 2020 Sep 9] Jakarta (ID) Gramedia Pustaka Utama.

https://books.google.co.id/books?id=8E2DC3sva3EC\&printsec=frontcover\&hl=id\&sour $\mathrm{ce}=\mathrm{gbs} \_\mathrm{ge} \_$summary_r$\& \mathrm{cad}=0 \# \mathrm{v}=$ onepage $\& \mathrm{q} \& \mathrm{f}=\mathrm{false}$.

[WHO] World Health Organization.2020 Sep 19. Sexual and reproductive health. [diakses pada 2020 Sep https://www.who.int/reproductivehealth/topics/gender_rights/sexual_health/en/\#: :text= as\%20WHO\%20definitions.-,Sex,humans\%20as\%20males\%20and\%20females.

Wijaya, Cece, et al. 1992. Upaya Pembaharuan dalam Pendidikan dan Pengajaran, Bandung (ID): Remaja Rosdakarya. Hlm 12.

World O Meter. 2020 Agu 19. COVID-19 CORONAVIRUS PANDEMIC. [diakses pada 2020 Agu 19]. https://www.worldometers.info/coronavirus/

Yusriani, Alwi MK. 2018. Buku Ajar Promosi Kesehatan dan Pemberdayaan masyarakat. Ponorogo (ID): FORIKES. hlm 1. https://www.researchgate.net/publication/326893019_20180527yusriani-promkesdanpemberdayaan_masy 